\title{
UYGUR TÜRK TOPLUMUNDA DEĞISSMENIN SONUCU OLARAK AYDINLARDA BÖLÜNMÜŞLÜK VE KÜLTÜREL KOPUKLUK
}

\begin{abstract}
Prof. Dr. Abdürreşit Celil Karluk*
ÖZ: Uygur Özerk Bölgesinin kurulmasıyla Doğu Türkistan Bölgesi politik ve coğrafi olarak tamamen Çin'e bağlanmış olmasına karşın, bölgenin sosyo-kültürel anlamda Çin'e tabi olması ancak ÇKP'nin Uygur Türk toplumunda radikal ve zoraki değiştirme uygulamalarını ısrarla sürdürmesi sonucunda 2000'li yıllardan sonra gerçekleşmeye başlamıştır. Özellikle dil, eğitim ve kültür alanındaki hızlı değiştirmelerin Şinciang ${ }^{1}$ Uygur Özerk Bölgesi (ŞUÖB)'nin kuruluşundan itibaren (1955-- ) başlandığı ve günümüzde hızla devam ettirildiği bilinmektedir. Yarım asrı geçen değişme veya değiştirme süreci sosyolojik açıdan zorunlu sosyo-kültürel değişme kategorisindedir. İşbu değiştirmeye bağlı olarak ortaya çıkan değişme realitesi, günümüz Uygur Türk toplumunda geri dönüşü imkânsız kültürel kopuşları ortaya çıkarmaktadır. Makalede, 2003-2013 yılları arasında gözlem ve sahadan elde edilen nitel veriler temelinde günümüz Uygur Türk toplumunun aydın tabakasını incelemiştir. Özellikle kültürel kopukluk olgusunu yaşatmakta olan Çin dilli Uygurlar grubu üzerinde ayrıntılı betimlemelerde bulunulmuştur.
\end{abstract}

Anahtar Kelimeler: Uygur Türk toplumu, kültürel kopukluk, değişme, Çin dilli Uygurlar.

Yıldırım Beyazıt Üni. İnsan ve Toplum Bilimleri Fak. Sosyoloji Böl. ackarluk@ybu.edu.tr Gönderim Tarihi: 23.06.2017 Kabul Tarihi: 25.10.2017

1 Çincesi Xinjiang/新疆: genel olarak “新=yeni 疆-hudut” anlamını taşıyor ise de, Çincenin yazı özelliklerinden hareket edenler işbu yer adının gayri resmî olarak "silah gücü ile ele geçirilen yeni toprak" anlamını sakladığını dile getirirler. Bu yer adı 1884'te Çinlilerce resmi olarak kullanılmaya başlandıysa da bölgenin yerli ahalisi olan Türkler tarafından yaygın ve zorunlu olarak kullanılmaya başlanması ancak ÇKP dönemi (1955) sonrasında mümkün olmuştur. Çinceye vakıf olmayan bir Türk genellikle bozuk (örn.: Şıncang) telaffuz ederler. Çin Halk Cumhuriyeti'nin Türkiye Cumhuriyetindeki başarılı diplomatik ve psikolojik girişimleri sonucunda, daha önceleri genellikle "Doğu Türkistan" olarak adlandırılan işbu bölge adı için artık "SINCAN" söyleminin yaygınlaştırıldığı bilinmektedir. Daha geniş açıklamalar için bakınız: Erkin Türkler, Sincan: Çin'in başarılı algı operasyonu, Türk Yurdu, Sayı 331, Mart 2015, S. 27-28. 


\title{
Cultural Fragmentation and Disorientation Among The Uyg- hur Intellectual Community as a Result of the Transformation in the Uyghur Turk Society
}

\begin{abstract}
Eastern Turkestan became a part of the China both politically and geographically when Chinese Communist Party (CCP) culminated the power struggle with Guomindang (Nationalistic Party) successfully in 1949. However, it took decades getting the Uyghurs under the complete socio-cultural influence of China due to the insistent and deliberate ethnic pressure policies of the CCP and it was after the 2000s. Especially the governmental pressures on language, education and culture of the Uyghurs was started with the foundation of Xinjiang Uyghur autonomous region in 1955 and been increasingly growing nowadays. These fifty years long sociocultural assimilation policies of CCP can be defined under the category of "compulsory socio-cultural change" from the perspective of the science of sociology. The reality of forceful change will trigger the irreversible cultural erosion in Uyghur Turk Society. This article, based on the research methodology of participant observation and qualitative data obtained from the interviews, investigated the intellectuals in Uyghur Turk Society between the years of 2003-2013. To understand the cultural disorientation phenomenon better, more detailed study has been especially made on the sample of Chinese spoken Uyghurs.
\end{abstract}

Key words: Uyghur - Turkish Society, Cultural Disconnection, Changing, Chinese spoken Uyghurs.

\section{Giriş}

Türk medeniyeti ve kültürünün teşekkülü ile gelişimi sürecinde müstesna yeri olan Uygur Türk toplumu 18. yüzyılın başlarından itibaren, yaşadığı iç savaşlar ve dış savaşlar sonucunda çöküş sürecini yaşamıştır. Bu süreç, parçası olduğu Türk-İslam dünyasında ortaya çıkan sosyal, ekonomik, politik ve kültürel gerileme ile bağlantılıydı. Umumi Türk toplumlarında beliren bu gerileme veya çöküşün ana sebepleri elbette kendi sosyal ve kültürel yapılarında ortaya çıkan sorunlar ile ilişkilidir. Ayrıca, bu çöküş süreci Avrupalıların yeni deniz yollarını keşfetmesi, ticaret bağlantı yollarının değişmesi; Türk-İslam medeniyetine alternatif olarak Batı' da ortaya çıkan Batı medeniyetinin yeni bir dünya düzeni inşa etme sürecine girişmesi, bu süreçte ortaya çıkan ve hızla yayılan sömürgecilik sistemleri ile de ilişkilidir. Türk yurtları 18. yüzyılın sonlarından itibaren Kuzeyden ve Batıdan Çarlık Rusya'sı, Doğudan ise Mançu-Qing imparatorluğunun sömürgeleştirici politikalarına maruz kalmıştır. 
Osmanlı hilafetine bağlı Kaşgar devletinin ${ }^{2}$ Mançu-Çin orduları tarafından ortadan kaldırılmasıyla (1878), Türkistan'ın doğusu 1884 yılında Xinjiang adıyla Çin'in yeni bir eyaletine dönüştürülmüştür (Jia, 2011: 1, 15). Çinli idareciler tarafından bölge Türkleri, ŞUÖB kuruluncaya kadar(1955) eğitim, kültür, din ve sosyal alanlarda bölgeyi idare eden Çinlilerden bağımsız kalmayı başarmıştır. Bunun temel nedenlerini aşağıdaki şekilde açıklamak mümkündür:

1. Günümüzde Uygur olarak adlandırılan Türkler, batısında bulunan soydaş ve dindaşları ile sosyal, kültürel ilişkilerini (en zor şartlarda olsa da) devam ettirmeye önem vermiş̧ir; ÇKP iktidarına (1949-- ) kadar ister Yarkent Se'idiye Sultanlığı (1514-1680) döneminde olsun, ister daha sonraki dönemlerde [örneğin, Yakup Beg (182?1877) hâkimiyetine (1864-1878) son veren (1878) Mançu-Qing sülâlesi (1616-1911) dönemi veya Milliyetçi Çin yönetimi döneminde (1912-1949)] olsun, batısındaki soydaşları ve dindaşları ile olan sosyo-kültürel ilişkilerini farklı düzeylerde devam ettirmiştir.

2. Bölge ÇKP iktidarına kadar (1949) genellikle Çin kökenli askerî valiler veya sivil bürokratlarca sömürü sistemi ile idare edilmiş (Zhang, 1987: 2), Uygur Türk toplumu, tebaası olduğu ülkenin Çin'in- egemen çoğunluğu olan $\mathrm{Hanzu}^{3}$ toplumuyla sosyal ve kültürel anlamda etkileşimde bulunmamıştır.

3. Bölgede hâkim millet olarak beliren Çinliler veya Mançuların yerel halk nezdinde istilacı olarak bilinmesi ve sürekli direnişle karşılaşması kalıcı iskân politikalarının uygulanamaması durumunu ortaya çıkartmıştır.

4. 1955 öncesine kadar bölgede yaşayan Çinliler genellikle idareci/memur, asker ve tüccar sınıfından oluşuyordu. Çin resmi makamlarının verdiği istatistiki verilere göre, 1950 öncesi Çinlilerin

2 Konu ile ilgili geniş bilgi için şu kaynaklara bakılabilir: Boulger, D. C., The Life of Yakoob Beg (Athalik Ghazi, and Badaulet; Ameer of Kashgar), Wm. H. Allen \& Co., London 1878; Âtıf, Mehmed, Kaşgar Tarihi (Bâis-i Hayret Ahvâl-i Garibesi), haz. İsmail, Vehbi, Cahit, Eysi Yayınları, Kırıkale 1999; Brophy, D. (2016). Uyghur Nation. Harvard University Press. Sayrami, Molla Musa, Tarihi Hamidi, haz. Enver Baytur, Pekin Milletler Neşriyatı, Pekin 1986; Hayit, Baymirza, Türkistan Rusya ile Çin Arasında, çev. Abdülkadir Sadak, Otağ Yayınları, Ankara 1975.

3 Çin'deki çoğunluk olan Çin milleti kendilerini Hanzu/汉族veya Hanren/汉人olarak adlandırırlar. Çin'deki milliyetlerin genel durumları ve etno-demografik özellikleri için bakınız: Abdureşit Jelil Qarluq, “Çin Halk Cumhuriyeti'ndeki Milliyetlerin Dağılımı ve Etno-Demografik Özellikleri”, Hacettepe Üniversitesi Türkiyat Araştırmaları Dergisi, 2009 Güz (11), s. 63-90. 
toplam nüfustaki oranı \%5 dolayında idi (Barnett, 1961; Freeberne, 1966). ${ }^{4}$

5. Bölgede ikamet eden Mançu-Çinli nüfus Müslüman Türk ahaliden ayrı olarak surlarla çevrilmiş olan askeri garnizonlarda-Yengi Şehir" "lerde- yaşıyor olması ve etnik ayırımcılık temelinde politika güdüyor olması (Jia, 2011: 7) onların işgal gücü olarak kalması durumunu pekiştirmiştir.

6. Bölgeye gönderilen idarecilerin temel kaygısı bölgenin kalkındırılması veya Çin'in diğer bölgeleriyle bütünleştirilmesinden ziyade, sadece kendi menfaatlerini ve mensubu olduğu çıkar grubunun menfaatlerini korumak, kollamak tarzında olmuştur.

7. Coğrafi olarak bölgenin Han Çinli bölgesinden uzakta olması, Çin anakarası ile Türk bölgesi arasında geçilmesi zor çöller veya insansız bölgelerin bulunması ${ }^{6}$ muhtemel Çinli-Türk etkileşimine de engel olmuştur.

8. Uygur aydınları ve kanaat önderleri, zenginler kendi toplumunun kalkınmasının reçetelerini siyasî haritada bağlı bulunduğu ülkenin

41949 yılına gelindiğinde bölgede yaşayan Han Çinlisinin toplam nüfusu askerler dâhil ancak 5\% civarındayken, buna karşın Uygurların 75\%, Kazakların 10\%, Moğolların $6 \%$, geri kalan Kırgız, Tatar, Özbek, Döngen ve Şibelerin 4\% civarında olduğu biliniyordu.

5 Mançu-Çin birlikleri bölgeyi ele geçirdikten sonra kendi garnizon, karargâh ve idari birimlerini Türk şehirleri içinde değil, yakınlarındaki stratejik yerlere inşa ettikleri, etrafı surlar ile çevrili olan yeni şehirlere kurmuştur. Bu durum halk arasında "Kona Şeher" ve "Yengi Şeher" ayırımının ortaya çıkmasına neden olmuştur. Kona/Eski şehirler, bölgede var olan yüzlerce veya binlerce yılllk Türk şehirleri olup buralarda genellikle Müslüman Türkler yaşarken, onlar tarafından "Yengi Şeher" diye adlandırılan yüksek surlar ile çevrili, Çinli askerlerce korunan uydu şehirlerde ise, genellikle sonradan gelip yerleşen veya bölgeyi idare eden Çinliler başta olmak üzere gayri Müslimler ve Müslüman Çinliler yaşıyordu. İdareci Çinliler ise, Müslüman Türklerin yaşadığı kentlere “Huicheng/回城” yani “Müslüman şehri” diye adlandırıyor ve kayıtlara öyle geçiriyorlardı. Kendilerinin yaşadıkları yeni kentlere ise "Hancheng/汉城” yani “Han Çinli Şehri”” adını veriyorlardı. Bu durum XUAR sonrası da değişmemiş fakat artan Çinli nüfusu ile yeni yeni uydu kentleri inşa etmiştir. Bu Çinli nüfusun baskın olduğu şehirler veya bölgelerin kalkınması için diğer Uygur kentlerinden daha fazla ayrıcalıklı politikaları uygulayarak ŞUÖB'deki kalkınmış, müreffeh kentlere dönüştürmüştür. Bu durum, göçmen Çinlilerin kalıcı iskân edilmesinde çok etkili olmuştur. Detaylı bilgi için bakınız: Jia, J. (2011). Whose Xinjiang? The Transition in Chinese Intellectuals' Imagination of the" New Dominion" During the Qing-Dynasty. Harvard-Yenching Institute Working Paper Series, S. 1-16; Alessandra Cappelletti (2016), Socio-economic disparities and development gap in Xinjiang: the cases of Kashgar and Shihezi, Edited by Anna Hayes, Michael Clarke, Inside Xinjiang Space, Place and Power in China's Muslim Far Northwest, Routledge.

6 Zhang zhızhong (1987), Ürümçi Söhbetidin Xinjiang Tinç Azat Bolğanğa Qädär, Çinceden Çeviren Razaq Malik, Ürümçi: Şincang Halk Neşiriyatı. S. 48-55. 
kültür merkezlerinde (örneğin Pekin, Şanghai, Nanjing) değil, kültürel açıdan mensubu olduğu Türk-İslâm kültür merkezlerinde (örneğin Buhara, Taşkent, Delhi, Kazan, İstanbul) aramıştır.

ÇKP iktidarı (1949) sonrasında, ülkedeki resmî ideoloji-Çin tarzı sosyalizm-bölgenin sadece politik ve coğrafi anlamda değil, sosyal ve kültürel anlamda da Çin'in ayrılmaz bir parçasına dönüştürülmesi için seleflerinden farklı olarak daha israrcı politikaları icra etmişlerdir. Bundan dolayı ÇKP Uygur Türk toplumuna yönelik radikal biçimde "dönüştürme projesi"” ni tavizsiz biçimde uygulamaya koymuştur. Özellikle din, dil, eğitim ve kültür alanındaki radikal uygulamaların ŞUÖB kuruluşundan itibaren (1955--) gerçekleştirilmeye başlandığı, Wang Lequan/王乐泉 (19942010) döneminden itibaren daha radikal, daha 1srarcı biçimde uygulandığ görülmüştür.

Wang Lequan döneminde özellikle aile, din, ekonomi kurumuna yönelik sert ve zorlayıcı uygulamalar yürürlüğe girmiş olup, bu dönemdeki bazı özel uygulamalarla özerk bölgenin esas halkı olan Uygur Türklerinin her alanda marjinalleştirilmesi ve her anlamda "yoksullaştırılarak" Çinli toplumuna tamamen bağımlı hale getirilmesi amacına uygun politikaları gerçekleştirilmiştir. Din kurumu ile ilgili bu dönemde uygulanmaya başlanan ve halen uygulaması devam eden uygulamalardan bazıları şunlardır:

- Özel din öğrenimi ve eğitiminin tamamen yasaklanması; 18 yaşından küçüklerin, üniversite, yüksekokul öğrencilerin, devlet memurlarının veya maaşlılarının tamamının dini faaliyetlerden men edilmesi. Cuma günleri ve Ramazan ayında camilerin sıkı denetime tabi tutulması. Dini ibadet yapması yasaklananların camiye girişlerinin engellenmesi ve girenlere caydırıcı cezalar verilerek anında icra edilmesi, gündelik hayatta kullanılan İslami sözcüklerin yasaklanması;

- Uygurların iktisadi faaliyetlerinin denetime tabi tutulması, bölgeler arası hareketliliğinin sınırlandırılması, bölge içi veya Çinlilerin yoğun olduğu bölgelerde ikamette sınırlama getirilmesi;

7 ÇKP iktidarı, ŞUÖB'de iktidarını pekiştirir pekiştirmez, Uygur Türk toplumunun temel taşlarına ve manevi enerji kaynaklarına yönelik amansız bir mücadeleyi sosyalist jargonlarla başlatmıştır. İşbu mücadele "yerli milliyetçiliğe karşı mücadele", "ayrıllıçı güçlerle mücadele", "feodal dini güçlerle mücadele", "Pantürkizmle mücadele", "Panislamizmle mücadele" ve 11 Eylül saldırıları sonrasında ise "terörizm ile mücadele" gibi kavramlar ile acımasız bir şekilde yürütülmüştür. Bakınız: MA Dazheng/马大正 (2016). Şincang'da “Radikallığ 1 Yok etme” mücadelesinin araştırılmas1/ 新疆“去极端化” 斗争探究 新㨽济范大学学报, 37(5), 1-5. Nicholas Becqueline, “Criminalizing Ethnicity: Political Repression in Xinjiang," China Rights Forum 1 (2004), Gardener Bovingdon, "The Not-So-Silent Majority: Uyghur Resistance to Han Rule in Xinjiang, " Modern China 28, no. 1 (January 2002): 39-78. 
- Eğitim ve kültür alanında daha önce serbest olan milli tarih, milli kültür çalışmalarının sınırlandırılması veya tamamen durdurulması, Turgun ALMAS benzeri Uygur kökenli tarihçi ve yazarların daha önce resmi olarak yayımlanmış eserlerinin tekrar eleştiriye açılarak toplatılması, bu kitapları bulunduran, okuyanların cezalandırılması;

- Uygur Türk tarihi ve kültürünü Çin tarihi ve kültüründen bağımsız araştırılmasına izin verilmemesi, resmi Çin tarihinin zorunlu olarak okutulması ve yaygınlaştırılması;

- Uygur bölgesindeki başarılı ve çalışkan Uygur kökenli lise öğrencilerinin Çin'in iç bölgelerine göndererek kendi toplumundan tamamen koparılması ve yeni bir sosyal grup---Neigaosheng-yaratılması;

- Çin dilli Uygurlara, Minkaohanlere daha fazla olanakların tanınması ve Uygur toplumunda Çin dillilerin çoğalması için özel uygulamalara başvurulması;

- Uygurların Pasaport almalarının neredeyse imkânsız hale getirilmesi, uluslararası etkileşimin tamamen kontrole tabi tutulması...

$\mathrm{Bu}$ uygulamaların sonucu olarak, günümüz Uygur toplumunda geri dönüşü imkânsız bazı kültürel kopuşlar, sosyal yarılmalar ortaya çıkmıştır.

\section{Araştırmanın Sorusu ve Metodolojisi}

Araştırmanın Sorusu: Araştırmanın ana sorunsalını Uygur Türk toplumundaki değişme/değiştirme esnasında beliren, kültüründen kopan, sürekli yabancılaşan aydınlar oluşturmaktadır. Bilindiği gibi aydınlar bağlı oldukları toplumların selameti açısından çok önemli işlevlere sahiptir. Çok uluslu ve çok kültürlü toplumlarda egemen konumda bulunmayan toplum veya toplulukların aydınlarında iki önemli işlev göze çarpar. İlki, bağlı olduğu toplumun sosyo-kültürel yapısının korunarak mevcudiyetinin sürdürülmesine çalışmasıdır. İkincisi ise, birinci işlevini yerine getirirken egemen toplum ile iyi ilişkiler kurarak kendi toplumunu egemen toplum karşısında en iyi şekilde temsil etmesi, gerektiğinde savunmasıdır. Yazarın daha önce Uygur aydınları üzerine yürüttüğü bir araştırma projesi ${ }^{8}$ ile başlayan incelemeleri işbu araştırmanın temelini oluşturmaktadır. Bu bağlamda araştırmamızın ortaya çıkmasına neden olan merkezi sorular şunlardır:

82006 yılında Çin Merkezi Milliyetler Üniversitesi Bilimsel Araştırmalar Birimi tarafından desteklenen "ÇKP iktidarı sonrası Pekin'e yerleşen Uygur Aydınlarının Egemen Toplum İle İlişkileri” araştırma projesi. İşbu proje ile ilgili yayın için bakınız: Abdureşit Jelil Qarluq, DonaldHugh McMillan, (2011), Towardsa 'Harmonious Society' A Brief Case Study of the post Liberation Settlementin Beijing of Uyghur Intellectuals and Their Relations with the Majority Society, Asian Ethnicity, 2011/1, P: 1-31, London. 
- Neden Çin Halk Cumhuriyeti'nin azınlık bölgelerinde, Çin anayasası, dini inanç yasası ve özerk bölgeler yasasında (azınlıklar için) vaat edilmiş olan (sosyal, kültürel ve politik) haklara aykırı uygulamalar yaygindır?

- Uygur Türk toplumunda değişmeler nasıl ve ne şekilde ortaya çıkmaktadır? Değişmenin ana nedenleri nelerdir?

- Eğitim ve kültür politikaları bir toplumu, özellikle aydınları nasıl etkilemekte, şekillendirmektedir?

- Uygur Türk toplumundaki Aydınlar nasıl ve ne şekilde farklı gruplara ayrılmışlardır?

Araştırmanın metodolojisi: Araştırma tamamen nitel bir araştırma olup veriler yazarın uzun yıllık saha deneyimi ve birikiminden elde edilmiştir. Makalede bahsi geçen Uygur aydın grupları (Uygur dilli Uygurlar, Minkaohanler, Neigaoshenglar ve Çin dilli Uygurlar) üzerindeki gözlem ve mülakat verileri yazarın Çin'den ayrıldığı Temmuz 2013 tarihine kadar devam etmiştir. Fakat yurt dıșında çeşitli ülkelerde yaşayan Uygur Türkü aydınlar üzerindeki gözlem ve çeşitli düzeylerdeki görüşmeleri devam etmektedir. Bu çeşitli mekân ve ortamlarda yapılan mülakatlar, katılımlı gözlemler makalenin en önemli verilerini oluşturmuştur. Ayrıca, Çince, İngilizce ve Türkçe (Uygur Türkçesi dahil) alan ve konu ile ilgili yapılmış bilimsel çalışmalar taranmış ve gerektiğinde istifade edilmiştir.

\section{Uygur Türk Toplumu}

19. yüzyılın ortalarından itibaren gelişen Batı sömürgeciliği, Batı dışı toplumların Batılılaşma veya modernleşme sürecine katılma zorunluluğunu ortaya çıkartmıştır. Adı geçen süreçte sömürge veya yarı sömürge konumunda olan Batı dışı toplumların çoğu, mevcut durumdan kurtulmak için farklı yol ve yöntemlere başvurduğu bilinmektedir. Rus ve Çin sömürgesine maruz kalan çeşitli Türk toplulukları, bünyelerini güçlendirmek, Rus ve Çin asimilasyonuna direnmek, çağdaş millet olabilmek için bahsi geçen modernleşme sürecine dâhil olmuşlardır. İstanbul-Kırım-Kazan üçgeninde gelişerek tüm Türk yurtlarını etkisine almış olan Türk Aydınlanma hareketi -Ceditçilik hareketi- Uygur Türk toplumunun çağdaşlaşma sürecinde de çok önemli izler bırakmıştır?.

9 Geniş bilgi için bakınız; Abdürreşit Jelil Qarluq'un şu yayınlarına bakılabilir: Ceditçilik Hareketi-Türk İslam Kültürünün Yenileşme Girişimi, Milliyetler Araştırması Külliyatı/ 民族研究文集Minzu Yanjiu Wenji Milliyetler Üniversitesi Yayınevi, 2007, 275-288, Pekin, (Çince); Musabayuf Ailesinin Şincang Yenileşmesi Sürecine Katkıları Üzerine İnceleme, Milliyetler Araştırması Külliyatı/民族研究文集Minzu Yanjiu Wenji, Mer- 
Uygur yenileşme sürecinin ŞUÖB kuruluncaya (Ekim 1955) kadar olan aşaması incelendiğinde, etkileşme ve yenileşmenin ilham merkezleri olarak İstanbul, Kazan, Taşkent karşımıza çıkacaktır. Çünkü, Uygur Türk bölgesi "Xinjiang-Şinciang" adıyla eyalete dönüşmesinden (1884) ŞUÖB kuruluncaya kadar olan süreçte, bölgeye gönderilen yöneticilerin esas kaygılarının bölge halkının eğitimi başta olmak üzere sosyo-ekonomik, sosyokültürel açıdan kalkındırılması yönünde olmadığı aksine yerliler lehine olan her müspet gelişmelerden şüphe duyarak engellediği bilinmektedir (Qarluq, 2009: 292). Dolayısıyla, Uygur aydınları özellikle eğitim sistemini kendi imkânları dâhilinde modernleştirmeye/dönüştürmeye, geliştirmeye uğraşması, tamamen özveriye dayalı şekilde çalışmalarına rağmen, resmi yönetim sürekli şüpheci ve düşmanca tutum takınmış, mümkün olduğunca ilgili bağlantıları kopararak izole etmeye çalışmışıır ${ }^{10}$. Bununla birlikte, Kaşgar, İli, Turfan gibi bölgelerin Çin'in Pekin, Şanghay, Kanton gibi siyaset, ticaret ve kültür merkezleri arasındaki mesafe, bölgenin bat1sında bulunan Buhara, Taşkent, Dehli, Kazan ve İstanbul arasındaki mesafeye nazaran daha uzak oluşu, ulaşımın çetin ve meşakkatli olması; Çinliler ile Türkler arasında dil, din ve kültür bağlamında ortaklığın hiç bulunmayışı gibi somut nedenler, Türklerin Çinlilerden sosyal ve kültürel olarak bağımsız kalmasına imkân vermiştir.

Malum olduğu üzere, 20. yüzyılın başlarından itibaren eski sömürge sistemleri çökmeye, parçalanmaya yüz tutmuş, aynı zamanda Avrupa menşeili ulus-devlet modeli yaygınlaşmaya başlamıştır. Diğer taraftan, modeli yeni, fakat mahiyeti eskisinden pek farklı olmayan, dışlayıcı ve eritici karakteri olan ideolojilerin rehberliğinde yeni imparatorluklar da teşkil etmeye başladığı bu yeni dönem de -Sosyalist Blok dönemi- başlamış bulunuyordu. Rus sosyalist imparatorluğunun teşkili ve onun özgün Milliyetler Politikası, kendinden olmayan millet, topluluklara "böl, idare et" stratejisini uygulatmış, geniş Türkistan ve Kafkas coğrafyasına yayılmış Türk kitlesini mahallî kimlikler veya yöresel adlar altında yeniden Millet olma yoluna sevk etmiştir.

kezi Milliyetler Üniversitesi Yayınevi, 2007, 260-275, Pekin, (Çince); Uygur Yenileşme Sürecindeki İstanbul Ekolü ve Onun Bazı Temsilcileri Üzerine, Türk Kültürrü Türk Kültürü Araştırmaları Dergisi, yıl 47 yeni seri cilt II, şayi 2, 2009/2, 290-328, Ankara; Uygur Yenileşme sürecinde 'İstanbul Ekolünün' Etkisi üzerine, Türk Kültürü̈, 2010/2, 72-112, Ankara;

10 Waite, Edmund, (2007). "The Emergence of Muslim Reformism in Contemporary Xinjiang: İmplications for the Uyghrs' Positıoning Between a Central Asian and Chinese Context", Situating The Uyghurs Between China And Central Asia , Ed.: Ildikó Bellér- Hann, M. Cristina Cesáro, Rachel Harris, Joanne Smith Finley, Angland: Ashgate Publishing Company, pp. 167. 
Bu bağlamda, asırlardan beri kendi millî kimliğini Türk olarak alg1layıp (en azından aydın, ulema tabakasınca), o şekilde "öteki” ile kendilerini ayırt eden bu milletin aydınları ve ulemaları gitgide saf dışı edilirken, yürürlükteki ideolojiye uygun veya buna yatkın yeni tip aydınlar sınıfı da hızla yetiştirilmeye başlanmıştı. Bu süreçte, Rusların doğrudan sömürgesi konumunda olmayan, sonradan onların genel politik etkisi ve yönlendirmesiyle de kendileri için reva görülen "Uygur" etnonimini millet adı olarak özümseyecek olan (Çin'in politik sınırları içinde kalan) Şark-i Türkistan Türklügünün aydın tabakası, milletleşme sürecinde yavaş yavaş genelde iki gruba ayrılmaya başlamıştır. Bunların ilki, millî geleneğe uygun şekilde kendilerinin de kabul ettiği geleneksel Türk-İslâm çizgisinde devam eden, daha çok Türk kimliğinin muhafazasından yana olan aydın-ulemalar grubu; İkincisi ise, SSCB sınırları içinde okumuş, ikamet etmiş ve Rus etkisinde kalmış olan daha çok Uygur adı ve kimliği ile milletleşmeye yatkın aydınlar grubudur (Qarluq, 2010: 90-99).

İlk gruptakilerin kimlik algılayışı önceleri Rusların daha sonra ise Çinlilerin soğuk ve dışlayıcı muamelesine maruz kalmıştır. Ruslar, bu grubun etkin olması durumunda, boyunduruğu altındaki Türklerin menfi yönde etkileneceği korkusundan hareketle bölgedeki Çinli yöneticileri yönlendirmiş ya da bizzat müdahalede bulunarak ${ }^{11}$ bölgedeki siyasal gelişmenin kendi çizgisi ve kontrolünde olmasına çaba sarf etmiştir. Daha sonraları Çin'de egemen olan, Rus sosyalizminden esinlenen Çin komünist ideolojisi de birinci grup aydınları ve onların zihniyetini tehlikeli bulmuş ve ŞUÖB' in kurulmasından hemen sonra yasaklamıştır. Onları "Pantürkist”, "Panislamist” ve “yerel milliyetçiler” şeklinde yaftalayarak ağır cezalara çarptırmıştır. Rus ve Çin yasaklarına rağmen gücünü ve enerjisini binlerce yıllık kimlik algılama geleneğinden alan zihniyet ve kültürel öz bilinç etkisini günümüze kadar sürdürmüştür.

11 SSCB yönetimi Doğu Türkistan bölgesindeki gelişmeleri yakından takıp etmiş ve işbu bölgeden sınırları içindeki Türk bölgelerine yönelmesi muhtemel tehditleri yerinde imha etme politikasını gütmüştür. Örneğin özellikle Türk-İslam çizgisinde olan aydınları potansiyel tehdit ve düşman olarak görmüştür. Mesut Sabri Baykuzu, Mehmet Emin Buğra ve Sabit Damolla ekibi dolayısıyla yeni kurulan Şark-i Türkistan İslam Cumhuriyeti hükümetinden duyduğu aşırı rahatsızlığını, bölgenin Çinli genel valisi Sheng Shıcai ve ihtilalci lider Hocaniyaz ile anlaşmak suretiyle Kızıl Orduyu Doğu Türkistan topraklarına sürerek Şark-i Türkistan İslam Cumhuriyetini ortadan kaldırarak belli etmiştir. Mesut Ependi bölgenin genel valisi olduğu dönemlerde bazı karışıklıkları çıkartmış, hatta Mesut Sabri ekibinin görevden alınması sürecini bizzat etkilemiş̧ir. Ayrıca, Rusların ikinci Şark-i Türkistan Cumhuriyetinin (1945-1949) önderi, Reis-i Cumhur Alihan Töre'yi tutuklayarak Taşkent'e götürmesi de onun Türkçü ve İslamcı kimliği ve fikriyatından duyduğu rahatsızlıkla doğrudan ilişkilidir. 
Günümüzde yaklaşık bir asırdır Rus ve Çin komünistlerinin anti Türk tutumu, parçalayıcı ve yıkıcı uygulamaları sonucunda Türk-İslam çizgisindeki grup, Uygur Türk toplumunda artık belirleyiciliğini kaybetmiştir. Fakat şunu da belirtmek gerekir ki, Doğu ve Batı Türkistan'da yaşayan diğer Türk soylulara nazaran günümüzde "Uygur" siyasi kimliğindekilerin Türklük şuurunun daha kuvvetli ve kapsayıcı olduğu rahatlıkla söylenebilir. Bağımsızlığını kazanmış Türk Cumhuriyetlerinde devlet destekli "Boy"culuk uygulamaları örneğin Kazakçılık, Özbekçilik, Kırgızcılık uygulamaları ve bu ülkelerde yaşayan Uygur Türklerine yönelik acımasız bastırma veya gereksiz yere tutuklamalar, hatta Çinlilere çeşitli uydurma bahaneler ile sorumsuzca teslim etmeleri durumu Uygur Türklerinde büyük hayal kırıklığı yaratmıştır. Bu tarz ötekileştirici ve dışlayıcı realite Uygur Türklerinde var olan kapsayıcı Türklük bilincine yıpratıcı etki yaptığı ise son yıllarda daha açık bir şekilde gözlenmektedir. Bundan dolayı diasporada yaşayan veya bağımsızlık mücadelesi içinde olanlar arasında "Uygur Milleti", "Uyguristan" söylemlerinin yaygınlaşmaya başladığı da biliniyor. Türkiye'de Şark-i Türkistan Millî Merkezi olarak kurulan Diaspora üst çatısının geçmişteki Türk yönetimlerince sürgüne gönderilmesi veya faaliyetlerinin yasaklanması sonucu merkez Almanya'ya taşınmış, daha sonra adını Dünya Uygur Kurultayı'na değiştirmiş olmasını ise bu bağlamda değerlendirilebilir.

İkinci algılayış biçimi ise, 1920'li yılların erken çağlarında, Bolşevik yönetiminin Türkistan Türklerini kendi ideolojisine uygun sınıflandırırken şekillenmeye başlamıştır. Batı Türkistan'da Bolşevikler, ekim devriminin hemen akabinde Türkistan Türklerini boy veya mahalli adlar temelinde ayrı "milliyet" olarak belirlemeye ve ayrıştırmaya başladığı s1ralarda, kendi sınırları dışında kalan Doğu Türkistan Türklerini de bu politika ve strateji kapsamında değerlendirmeyi uygun görmüştür. Bolşeviklerin işbu uygulaması Batı Türkistan'da yaşayan veya geçici ikamet eden bazı Doğu Türkistan kökenli aydınların da desteğini kazanmıştır. 1921 yılında toplanan Taşkent konferansında Doğu Türkistan'da yaşayan yerleşik Türklerin millet adının "Uygur" olmasına karar verilmiştir (Kamalov, 2007: 32). Bu süreçte, Rus Türkologlarının ve mevcut ideolojinin etkili hem de belirleyici olduğu kesindir. Türkistan'da Ruslar tarafından başlatılan Türklerin bölünerek "milletleştirilme" sürecini yakinen takip eden Sovyet sınırları içinde yetişen yerli Uygur Türk aydınları ve Sovyetlere öğrenim amaçlı gelen Doğu Türkistanlı aydınlar, Ruslar tarafından belirlenen "Uygur" adını nispeten kolayca benimsediklerini düşünmek mümkündür. Daha sonraki süreçte işbu aydınlar grubu "Uygur" adının Tanrı dağının kuzey ve güneyinde yerleşik hayat tarzı sürdüren Türklere millî ad olarak yaygınlaştırılması ve benimsetilmesi hatta resmî kimliğe dönüştürülmesi sürecini hızlandırmıştır. 
ŞUÖB kurulmasıyla Çinli idarecilerde Ruslar tarafından geliştirilen (Özellikle, Türklere yönelik) 'Milliyetler Politikası'nın sosyalist jargonları ile kendi geleneksel düşünce sistemindeki "ötekilere” yönelik uygulamalarını birleştirerek daha sistematik, daha kontrollü ve kendi çıkarları açısından daha akılcı yeni tarz milliyetler politikasını geliştirdi ve sistemleştirdi. İşbu politikanın sistemli olarak uygulanması sonucunda yukarıda bahsi geçen ikinci grubun zihniyeti artık Uygur Türk toplumunda belirleyici konuma geçmiş ve rejim tarafından da desteklenmiştir.

Fakat, ÇKP'nin Uygur Türk bölgesinde her alanda üstünlüğü elde ettiği 1994 sonrası süreçte ise, ÇKP yönetimi, Türkçü kimlik algısına karşı destek verdiği Uygurcu kimlik anlayışının totaliter ve asimilasyoncu rejim karşısında tekrar bir milli birlik oluşturmasında aynı derecede etkili olduğunu, dolayısıyla rejimin farklı milletleri kaynaştırarak oluşturmak istediği "Çin milliyeti-Zhonghua Minzu" projesi ve sürecine engel olabileceğini de görmüştür. Bundan dolayı daha önceleri "Türk" demeyi resmen yasaklayan yöneticiler artık "Uygur" demeyi de bölücülük yapmak, Çinlileri dışlamak ve milliyetler birliğine/ittifakına zararlı olarak algılamış veya algılanmayı mecbur kılmıştır. Resmi ve popüler söylemde artık "Uygur" yerine "Millî" sözcüğünü yerleştirmeye ve komünist aydınlar, idareciler ve medya aracılığ ile yaygınlaştırmaya başlamıştır. Gündelik dilde ve resmi söylemde ister Çince veya Uygurcada "milli" sözcüğü "Uygur" yerini almıştır. Bölge ÇKP yönetimi, Uygurların Çin milletinin bir parçası olduğu fikri ve bilincini (artık 2003 yllından sonraki Çince eğitim-öğretimin Uygur Türkçesiyle eğitim-öğretimin yerine geçmesi ile) ana okuldan itibaren yerleştirmeye başlamıştır. Bu süreç şu an son sürat istikrarlı bir şekilde devam etmektedir. Bu durum adeta bir tarz hafıza kazınması ve yeniden hafıza oluşturulması süreci olmuştur. Bu duruma itiraz eden veya mevcut Çin yasaları çerçevesinde eleştiren aydınlar ekonomist Profesör İlham Tohtı örneğinde müebbet veya daha ağır cezalar ile cezalandırılarak sindirilmiştir.

Kısacası, geleneksel Türkistan toplumlarındaki sosyal, kültürel ve psikolojik parçalanmanın aslında sömürgecilik dönemi ile birlikte daha da hız kazandığı söylenebilir. 20. yüzyılın başlangıcında aydınlar tabakasında ortaya çıkmış olan bu ikilem daha sonraki süreçte Özellikle, ÇKP iktidarının bölgede mevcudiyetini tamamen pekiştirmesinden sonra dallanarak budaklanarak devam etmiştir.

\section{Kültürel Kopukluk Olgusu}

Etkileşmeyen ve değişmeyen bir kültürü tahayyül etmek imkânsızdır. Kültürler arası iletişim veya etkileşim doğal olduğu kadar suni, eşit olduğu gibi eşitsiz, doğrudan olduğu gibi dolaylı olabiliyor. Yaşam gücü 
kuvvetli kültürlerin öteki kültürlerden etkilense de nihai olarak yaşam gücü nispeten güçsüz kültürleri derinden etkilediği gibi tamamen kendi içine alarak eritebildiği milletler tarihinde sıkça rastlanmıştır. Özellikle, etkileşim eşitsiz ilişkiler temelinde gerçekleştiğinde bu etkilemenin zorunlu kültür değişmelerini ortaya çıkartabileceği sömürgeci ülkeler pratiğinde sıkça rastlanmıştır.

Kültürlerin etkileşiminde ortaya çıan önemli bir durum ise, kültürel kopukluk durumudur. Kültürel kopukluk, farklı kültürler arasında etkileşim yaşanıldığında, özellikle eşitsiz etkileşim gerçekleşmeye başlandığında ortaya çıkacak olan sosyolojik bir olgudur. Kültürel kopukluk durumu, belirli bir kültür mensubunun tabi olduğu toplumdan ayrılarak yabancı bir kültür içine göç etmesi sonucunda da ortaya çıkabilecektir.

Kültürel kopukluk olgusu genellikle hızlı sosyal ve kültürel değişimin yaşanıldığı toplumlarda ortaya çıktığı gibi yabancı güçler tarafından istila edilmiş toplumlarda veya yabancı kültür taklitçiliğinin yaygın olduğu topluluklarda daha açık olarak ortaya çıkabilmektedir. Modernleşme ile birlikte bazı toplumlarda ortaya çıkan Batılılaşma olgusu, modernleşmeye çalışan toplum veya topluluklarda gözle görülür külttürel kopukluğu ortaya çıkartmıştır. Bunun en bariz örneklerini Türkiye, Pakistan ve Kore gibi ülkelerde rahatlıkla görmek mümkündür.

Uygur Türk toplumu ve kültürü ŞUÖB döneminden itibaren, bilhassa 1990'lı y1llardan sonra Çinli toplumu ve kültürü ile doğrudan fakat eşit olmayan dengesiz bir etkileşim sürecine girmiştir. Bu durum, tamamen egemen milliyet konumundaki Han Çinlilerinin zihniyeti ve milliyet yapıları ile alakalı olmuştur. Çinliler genellikle farklı milliyet veya kültürlerle olan ilişkilerinde, karşı toplum veya milliyete üstünlük sağlayana kadar nispeten eşitlikçi ilişkilerden yana olurken, nüfusça ve nüfuzca üstünlüğü sağladıktan sonra kendi dili ve kültürünü zorlamaya, hatta karşı tarafa ait sosyal, kültürel, dini, politik ve ekonomik bütün özelliklerin kaybolmas1 için çeşitli uygulamalara başvururlar. Kesintisiz üç bin yıllık medeniyet tarihi olan Çin uygarlığının, farklılıklarla nasıl ilişki kurulması konusunda kurumsallaşmış kültürü ve felsefesi mevcuttur. Çinlilerin ŞUÖB'de nüfus ve nüfuz alanında Uygurlara nazaran üstünlük sağlaması ancak 1990 sonrasında gerçekleşmeye başlamıştır. Bölge'de uygulamaya koyduğu kendi yasalarına aykırı olan çok sayıdaki politik uygulamalarının uluslararası arenada meşru gösterilebilmesi ise 11 Eylül saldırısı sonrasındaki konjonktürel süreç ile tamamen mümkün olmuştur. Bu süreçte Uygur Türk toplumu harici uygulamaların etkisiyle sürekli olarak parçalanma, çeşitli sosyal gruplara bölünme sürecine itilmiştir. Farklı sosyal gruplar arasın- 
daki en önemli belirti asli Türk İslam kültüründen kopma, Han Çinli kültürüne sürekli yakınlaşma / yakınlaştırılma veya içinde erime/eritme tarzında devam etmiştir.

Umumi Uygur Türk toplumlarında ${ }^{12}$ ortaya çıkan kültürel kopukluk olgusu öncelikle Çin dilli, Rus dilli ve Arap-Urdu dilli Uygurlarda ortaya çıkmıştır. Bu makalede, kültürel kopukluk olgusunu (günümüzde) tüm çıplaklığı ile canlı olarak yaşatmakta olan Çin dilli Uygurlar grubuna odaklanarak açıklamaya, dolayısıyla Uygur Türk toplumundaki şiddetli sosyal yarılma ve parçalanmalara dikkat çekilmeye çalışılacaktır. Diğer taraftan sosyoloji literatüründe pek dikkat çekmeyen aslında zengin malzeme barındıran, kültürel çeşitliliklere tehdit olan Çin tarzı asimilasyonun anlaşılmasına da 1şık tutulacaktır.

\section{Günümüz Uygur Toplumunda Sosyal Gruplar}

Bilindiği üzere, değişmeyen toplumu düşünmek imkânsızdır. Fakat değişmenin hangi seyirde (serbest/aktif, zorunlu/pasif) gerçekleştiği veya gerçekleşmekte olduğu ise sosyolojik açıdan önemlidir. Sömürgeleştirilme süreci ile karşı karşıya kalmış veya sömürgeleştirilmiş toplumların çoğunda ortaya çıkan sosyal ve kültürel değişmelerin çoğunun ise, pasif veya zorunlu değişme olduğu bilinmektedir. Uygur Türk toplumu, tahminimize göre, ilk radikal sosyal ve kültürel değişimini İslamiyet ile şereflenen Karahanlılar döneminde yaşamıştır. Bu dönemden sonraki en radikal sosyal ve kültürel değişimini belki 1955 sonrası ÇKP yönetiminde yaşamaya başlamıştır. Bu süreç henüz sonuçlanmamış fakat son sürat devam eden canlı bir süreçtir. Dolayısıyla, günümüz Uygur toplumundaki sosyal ve kültürel değişmeler genellikle yönlendirilmiş veya zorunlu olarak tepeden tabana yayılmaya çalışılan sosyal ve külttürel değiştirme sürecidir.

ÇKP, "reform ve açılma" süreci ile sınırları içindeki azınlıklara yönelik başlattığı mutedil, nispi eşitlikçi politikalarını soğuk savaşın sona ermesi ve SSCB'nin dağılmasından sonra değiştirmiştir. 1990 sonrasında ÇKP, Çin vatandaşlarına, bilhassa azınlıklara yönelik Çin anayasası dâhil çeşitli yasalar tarafından tanınan sosyal, kültürel, eğitim ve politik alanlardaki haklarını kademeli olarak sınırlandırmaya gitmiştir. Özellikle, özerk bölgelerde uygulanması beklenen özerklik yasalarının Uygur ve Tibet bölgelerinde giderek uygulanmaması veya özerklik hakkı bulunan milliyet aleyhinde değiştirilerek uygulanması durumu, Uygur Türkleri ve Tibetli-

12 Günümüzde Uygur Türklerinin mutlak çoğunluğu resmi adıyla ŞUÖB olan Doğu Türkistan' da yaşamakla birlikte, sayıları gayri resmi olarak iki milyonu geçen Uygur Türkü başta SSCB'den ayrılan Türk Cumhuriyetleri olmak üzere Pakistan, Afganistan, Arabistan, Türkiye, $\mathrm{AB}, \mathrm{ABD}$, Avusturalya, Japonya gibi ülkelerde yaşamaktadır. 
lerin büyük sorunlarla yüzleşmesine neden olmuştur. Çin'deki egemen toplum ve kültürden tamamen farklı yapı ve özelliğe sahip olan Uygur Türk toplumu ve kültürünün kendini savunma, koruma ve geliştirme mekanizması hızla işlevsizleştirilerek sosyal ve kültürel alanda bölünme, parçalanma ve nihayetinde egemen kültür içinde eriyip gitmesi yönü belirginleştirilmiştir.

ÇKP yöneticileri, 30 küsur yıllık hızlı kalkınma sürecinde uyguladıkları öncelikli bölgesel kalkınma stratejisinin ortaya çıkarttığı çeşitli sosyal sorunları politize ederek veya sorunu çok yönlü araştırmadan tek taraflı çözme yoluna gitmiştir. Bunun için, baskıcı, zorba yönetim anlayışı ÇKP'de egemen olmuştur. Bütün sorunları ekonomik göstergeler temelinde okuma alışkanlığı ağır basınca istikrar vurgusu ön plana çıkmıştır. Bu durum, "devlet çıkarı her şeyden üstündür" anlayışını düstur edinen yöneticilerde rüşvet ve yolsuzluğu sıradanlaştırmıştır. Bunun akabinde özellikle azınlık bölgelerinde ülke yasalarını hiçe sayan Wang Lequan örneğinde yerel diktatör krallar ortaya çıkmıştır. İstikrar, ekonomik büyüme ve ülkenin sosyo-kültürel bütünlüğünün sağlanmasında öncelik, farklılık tehdittir anlayışı ile tek dilli, tek kültürlü eğitim, kültür politikasına geçilmiştir. Son on beş yılda gitgide derinleştirilerek uygulanan Çin yasalarına aykırı yerel politikalar aslında ülke gerçeğine (çok milliyetli ve çok kültürlü) ve medeni dünyada üstün değerler olarak kabul edilen çoğulculuk anlayışına tamamen aykırı düşmüştür. Tek milliyetlilik (Zhonghua/Çinli Milliyeti) ve tek kültürlülük (Han Çinli kültürü) politikalarının tavizsiz bir şekilde uygulanmasına devam edilmektedir. Bu uygulamalar çerçevesinde oluşturulan sosyal, ekonomik, dil, din ve kültür politikaların Uygur, Tibetli ve Moğol benzeri milliyet toplumlarında önemli ölçülerde amacına ulaştığı gözlenmektedir.

Sonuçta, günümüz Uygur Türk toplumunda sosyal, kültürel olarak parçalanmışlık, ekonomik olarak zayıflatılmıştık ve bağımlılık durumu ortaya çıkmıştır. Devam etmekte olan bu süreç, Uygur toplumunda geri dönüşü veya tamiri imkânsız sosyal yarılma ve sosyal parçalanmaları gerçekleştirmiş, sosyolojik manada kültürel kopukluğu tüm yönleri ile yaşatan yeni sosyal grupları ortaya çıkartmıştır. 


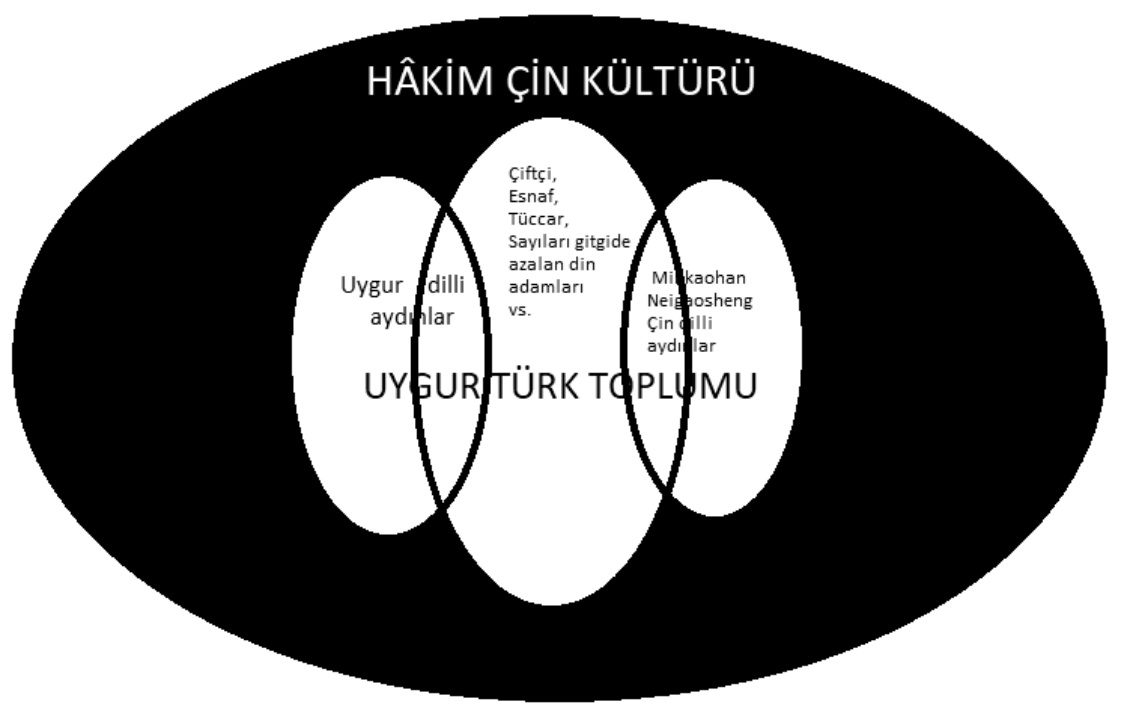

Şekil 1 Siyah Çin kültürï ile kuşatılmış beyaz Uygur Türk toplumu ve mevcut sosyal gruplar

Özellikle bahsi geçen politika ve uygulamalar sonucunda Uygur Türk toplumundaki aydınlar kitlesi Uygur dilli Uygurlar (Minkaomi/民考 民), Minkaohan'ler (民考汉), Çin dilli Uygurlar (Xentilliq Uygurlar) ve Neigaosheng'lar(内高生) olmak üzere birbiri ile anlaşmakta zorluk çeken, birbirinden farklı değer yargılara sahip çeşitli sosyal gruplara bölünmüş̧ür. Aydınlar haricindeki kitle genellikle kırsallarda yaşayan çiftçiler, kent ve kasabalarda yaşayan esnaflar, tüccarlar ve sayıları şiddetle azalan din adamlarıdır.

Uygur Dilli Uygurlar: Günümüz Uygur toplumunda sayıca çoğunlukta olan, fakat 2003'de uygulamaya konulan «Çift dilli eğitim» ${ }^{13}$ politikasının tavizsiz uygulanmasından sonra nitelik ve nicelik bakımından gerilemeye başlayan gruptur. Çince Minkaomin/民考民olarak adlandırılır.

13 Çin'de hâlâ çok tartışmalı olan ancak sorgulanması devlet tarafından pek hoş karşılanmayan, özellikle kendi yazı ve dilleri ile ilk, orta ve yüksek öğrenimini sürdürebilen Uygur, Tibetli ve Moğol toplumlarında zorunlu olarak uygulamaya konulan bir devlet politikasıdır. İşbu politikanın adı "Çift dille eğitim” olup uygulamada ise, sadece Çincenin geçerli dil sayıldığı, Uygur, Tibet ve Moğol dillerinin dışlandığı bir çeşit eğitim ve kültür politikasıdır. Özellikle, Uygur bölgesindeki dil politikası uygulamaları için bakınız: Dwyer, A. M. (2005). The Xinjiang conflict: Uyghur identity, language policy, and political discourse. Policy Studies, (15), I. Schluessel, Eric T. (2007) "Bilingual' education and discontent in Xinjiang', Central Asian Survey, 26: 2, 251-277; Hann, 
Uygur dilli Uygurlar, umumiyetle sadece Uygur Türkçesinden başka dil bilmeyen ailelerde doğmuş; ilk, orta ve liseyi Uygur Türkçesi ile tamamlayarak üniversiteye giden, üniversite öğrenimini genellikle Uygur Türkçesi ile bitirmiş bireylerdir. Onların birinci dili Uygur Türkçesi olup Uygur Türkçesi ile düşünür ve o şekilde konuşurlar, yazarlar. Çinceye vâkıf, belirli seviyede İngilizce veya diğer yabancı dilleri bilen; İslami inancını kaybetmemiş veya geleneksel Uygur Türk-İslam zihniyetini devam ettirmeye çalışan; Büyük çoğunluğu Çinlilere rezerve koyan, gayri Türkler ile karışık evlilik yapmayan kimselerdir. Uygur dilli Uygurlar yani Minkaominler, Çinliler veya Çin dilliler (Çin dilli Uygurlar dâhil çeşitli milliyet mensupları) gözünde genellikle «ehlileştirilmesi» gereken, pek istenilmeyen, görmezden gelinebilecek gruptur.

Uygur dilli Uygurlar, özerk bölge yönetimi ve idaresinin çeşitli kademelerindeki etkinlikleri 11 Eylül saldırısı sonrasında değişen konjonktürel süreçte kademeli olarak sınırlandırılmaya hatta tasfiye edilmeye başlanmıştır. Bu grubun üyeleri, gerçi politik olarak beklenen seviyede "Çinli”leştiği gözlendiyse de sosyal, kültürel ve psikolojik olarak yeterli düzeyde "Çinli" olamayışı, sayıları gitgide çoğalan Çin dilliler kadar "aktif" ve "sinyal/mesaj alıcı" olamayışlarından ötürü, ÇKP sekreterlerinin gözlerinden düşmüştür.

ÇKP yönetiminin 2000'li yıllardan sonra, Uygur özerk bölgesinin yönetimi ve bürokrasisinde Çin dilli Uygurları veya Minkaohan'leri tercih etmeye başlamasıyla Uygur dilli Uygurların artık hızla saf dışı edildiği açık olarak gözlenmeye başlanmıştır. Özellikle, Çinli ÇKP yetkilileri her alanda kendisiyle iyi anlaşan, karşı gelmeyen hatta isteyip dillendirmekte tereddüt ettiklerini dahi düşünüp önceden yapabilen, Çin kültüründe yetişen Minkaohan veya Çin dilli Uygurları yasalar ve yönetmelik gereği Uygurların bulunması gereken mevkilere atamıştır. Sonuç olarak, genellikle politik arenada Uygurları, Uygur Türkçesi ve kültüründe yetişen Uygur dilli Uygurlar değil, artık bahsi geçen Çin dilliler veya Minkaohanler temsil etmeye başlamıştır.

Minkaohan'ler/民考汉: Aslında kendi dili ve yazısı olan, Çinli olmayan Uygur, Moğol veya Tibetli gibi milliyetlerin lise mezunları üniversite giriş sınavına kendi dillerinde yapılan bölgesel sınava değil, Çin dili ve yazısı ile yapılan ulusal üniversiteye giriş sınavına (Gaokao/高考) gir-

C. (2014). Harmonious or Homogeneous? Language, education and social mobility in rural Uyghur society. On the fringes of the harmonious society: Tibetans and Uyghurs in socialist China, 183-208; Gupta, S., \& Veena, R. (2016). Bilingual Education in Xinjiang in the Post-2009 Period. China Report, 52(4), 306-323. 
TÜBAR XLII / 2017-Güz / Uygur Aydınlarda Bölünmüşlük ve Kültürel Kopukluk

melerinden ötürü, Çinliler tarafından Minkaohan/民考汉 olarak adland1rılmıştır. Bu adlandırma esasında, etnik Çinlilerden veya ana dili ve milli yazısını çoktan kaybetmiş olan diğer milletlerden ayırmak, Minkaohan diye adlandırılan grubun Çince ulusal sınava katılmalarından ötürü ödül ödül puan verilerek kendi dili ve yazısı ile üniversite sınavlarına katılan diğer akranlarından daha iyi üniversite ve bölümlere girmesini sağlaması ve öteki akranlar arasında bir statü kazandırma işlevini görüyordu. "Minkaohan" kavramın doğrudan anlamı ise "Azınlık milliyetinden Çince S1nava Girenler" şeklindedir. Zamanla Minkaohan adı bu grup insanların genel adı olarak bir tanımlamaya dönüşmüştür.

Uygur Türk bölgesinde, sosyal ve kültürel özellikleriyle daha belirgin olan Minkaohan grubu, sosyolojik açıdan şöyle tanımlanabilir:

Biyolojik olarak Uygur Türk ana-babadan doğma, nüfus cüzdaninda ve kimliğinde "Uygur" yazllan, fakat eğitim ve etkileşim çevresinden dolayı kültürel olarak daha çok Çinli olan bireylerdir. Bu gruba mensup bireyler doğdukları yörelerde Uygur okullarının bulunmayışı veya ana-babasinın isteği üzerine ana okuldan itibaren Çin dili ve yazısı ile eğitim-öğretim yapan Han Çinli okullarına verilmek sureti ile Çince eğitim süzgecinden geçmişlerdir. Üniversiteye giriş sinavlarında Çinlilerle aynı sinava girmesinden ötürü ekstradan ödül puan ${ }^{14}$ ile ödüllendirilmiş ve kontenjan sinırlamasina ${ }^{15}$ maruz kalmadan Çin'deki çeşitli üniversitelere gidebilmişlerdir. Çinlilerle aynı sinuflarda, yurt odalarında kalarak öğrenimine devam etmiş, arkadaşlık çevresi genellikle Çinli veya Çin dilli kimselerden oluşmuştur. Uygur dillilere uygulanan üniversiteye giriş̧ kontenjanı ve kota uygulamasina maruz kalmadiklarindan dolayı popüler meslekler, tıp ve mühendislik benzeri önemli branşlara girebilmişler ve mezuniyet sonrasinda daha iyi iş bulabilmişlerdir.

Buna benzer somut gerekçeler onların sayısının giderek artmasındaki önemli etkenler olmuştur. Bu nicel artış, 2003 sonrasında uygulanacak sözde "Çift dilli" pratikte ise "tek dilli eğitim" politikasının hızla uygulanması için de önemli bir gerekçe oluşturmuştur. Aslında 2003 öncesinde

14 Azınlıkların Çince eğitim-öğretime katılmasını, dolayısıyla Çin kültürü ile kültürlenmesini teşvik etmek amacıyla uygulanan bir uygulamadır.

15 Uygur dilli Uygurlar, üniversiteye giriş sınavlarına Uygur Türkçesi ile girerler, bu sınav devlet tarafından tanınan fakat sadece Uygur Özerk Bölgesi sınırları içinde yapılıyordu. Sınav sorular ve yabancı dil, Çince yapılan ulusal üniversiteye giriş sınavından farkl1dır. Sosyal bilgilerde Uygur dili ve kültürü ağır basarken, yabancı dil yerine Çin dili ve edebiyatından girerler. 
Uygur Türk bölgesinde uygulanan eğitim politikalarının gizli amaç ve işlevlerinden birinin Minkaohan'lerin sayılarının arttırılması yönünde olduğu daha sonra bölge aydınlarınca anlaşılmıştır.

Minkaohan grubunun büyük çoğunluğunun birinci dili Çincedir, çoğu farklı düzeylerde Uygurcanın konuşma dilinden haberdarlar, fakat yazı dili ve kültürü hakkındaki bilgileri genellikle yetersizdir; dini inançları ve din kültürleri çok zayıf olmakla birlikte bakış açıları genellikle olumsuzdur. Arkadaş çevresi ise, çoğunlukla Çinli veya Çin dilli kimselerden oluşur. Onların eş-dost seçme eğilimleri genellikle Çinli/Çin dilli veya Çin kültürüne sempati ile yaklaşan kimselerdir. Çin'deki kimlik, nüfus cüzdanı uygulamalarından dolay $1{ }^{16}$ politik mensubiyeti "Uygur" olmasına karşın, kültürel ve psikolojik mensubiyeti genellikle Çinlidir. Fakat etnik ilişkilerde Çinliler tarafından "Uygur" kimliği ve ad soyadının Çince olmamasindan ötürü pek benimsenmezler. Diğer taraftan, Uygur dilli Uygurlar tarafından kültürel mensubiyetinin daha çok "Çinli" gözükmeleri ve Uygur Türk örf adetleri ile inançlarına yabancı olmalarından ötürü de dışlanırlar. Bundan dolayı bir çeşit hibrit kimlik sergilerler ${ }^{17}$.

Bundan dolayı Minkaohan'ler halk tarafından ŞUÖB'de 14. Millet, Çin genelinde ise 57. Milliyet ${ }^{18}$ şeklinde sınıflandırılmışlardır. Bu durum ise, onların politik mensubiyetinden ziyade kültürel mensubiyette Çinliliğin baskın olmasına karşın "Uygurluk" belirtilerinin de bulunuşu, kendilerini Çinlilere yakın hissetmesi ve ona uygun davranmalarına karşın

16 Çin Halk Cumhuriyeti vatandaşlarının yanlarında taşıma zorunluluğu olan kimlik belgesinde şu bilgiler yer alır: (Belgenin ön tarafındaki bilgiler) Adı-Soyadı, Cinsiyeti, Milliyeti, Doğum Tarihi, İkamet Adresi, Vatandaşlık kimlik numarası; Belgenin arka tarafında ise, Çin Halk Cumhuriyeti Vatandaşları Nüfus Cüzdanı Yazısı, Belgeyi Düzenleyen/veren Birim, Belgenin Geçerlilik Süresi.

17 Daha geniş bilgi için bakınız: TAYNEN, Jennifer, (2006), "Interpreters, Arbiters or Outsiders: The Role of the Minkaohanin Xinjiang Society", Journal of Muslim Minority Affairs, Vol. 26, No. 1, pp. 45-62; SEAN R. Roberts, (2007), “Ethnic Anomaly' or Modern Uyghur Survivor? A Case Study of the Minkaohan Hybrid Identity in Xinjiang", Situating The Uyghurs Between China And Central Asia, Ed.: Ildikó Bellér-Hann, M. Cristina Cesáro, Rachel Harris, Joanne Smith Finley, Angland: Ashgate Publishing Company, pp. 219-239.

18 Çin'deki resmi söylemde ŞUÖB'de yerli 13 milliyet vardır. Tüm Çin'de ise 56 milliyet vardır. Daha geniş bilgi için bakınız: Abdürreşit Jelil Qarluq, "Çin Halk Cumhuriyeti'ndeki Milliyetlerin Dağılımı ve Etno-Demografik Özellikleri”, Hacettepe Üniversitesi Türkiyat Araştırmaları Dergisi, 2009 Güz (11), s. 63-90. 
Çinlilerce özümsenmemesi farklı bir grup olarak algılanmasından kaynaklanmaktadır.

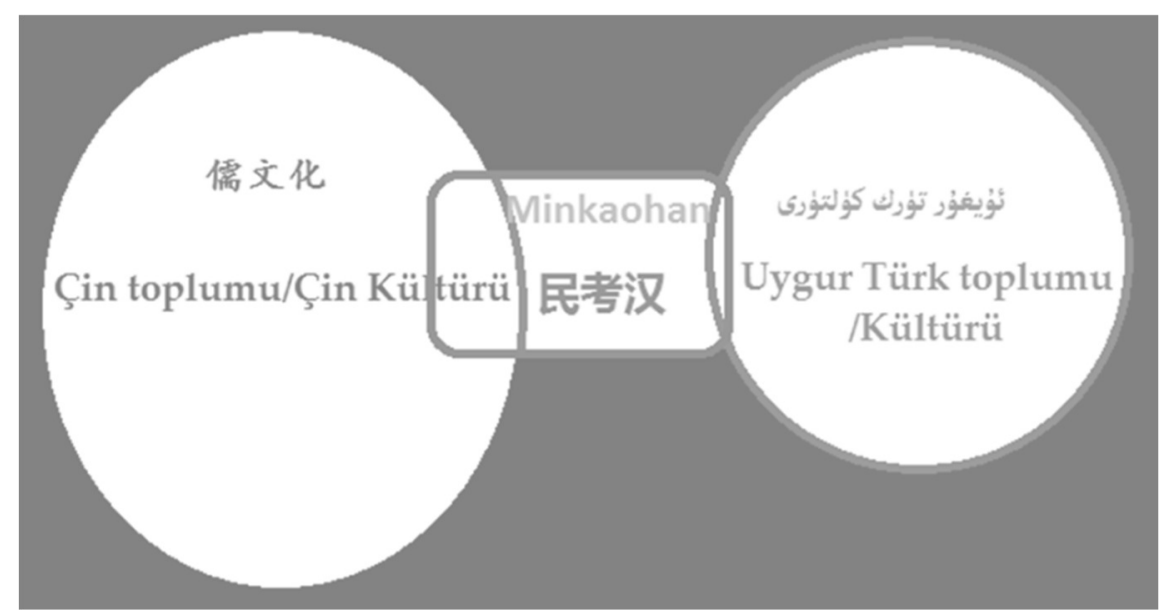

Şekil 2 Çin ve Uygur Türk toplumları arasında marjinal fakat hibrit grup olarak Minkaohanlar

Minkaohan grubuna mensup çok az sayıda aydınların, aile terbiyesindeki ısrarlar veya daha sonraki etkileşimler, düşünce dünyasında beliren değişimler, bireysel çabalar sonucunda kendi ana dili ve kültürüne dönüş yaptıkları, Çin dili ve kültürü üzerindeki artısını kendi milli çıkarları doğrultusunda değerlendirdiği; Çin-Uygur toplumları arasında köprülük işlevleri görmeye çalıştıkları da görülmüştür.

Neigaosheng /内高生Grubu: ÇKP yöneticilerinin ŞUÖB'deki Müslüman Türklere yönelik sosyal, kültürel, ekonomik ve politik uygulamalarına genel olarak bakıldığında konjonktürel olduğu görülmekle birlikte temelde değişmeyen bazı stratejilerin olduğu anlaşılmaktadır. Özellikle, bölgedeki göçmen Çinli nüfus baskın hale gelene kadarki uygulamalarda yönetimin daha temkinli olduğu ve yerlilerin kültürel olarak (kontrollii) homojen kalmasına nispeten kayıtsız kaldığı veya bilinçli olarak egemen toplumdan her alanda geride kalması için bazı uygulamalara başvurduğu gözlenmektedir. Örneğin, eğitim-öğretim alanında Çin'deki yaygın dil olan Çincenin Uygur okullarında zorunlu dil olarak okutulmadığı, üniversiteye kabul edilenlerin ise önce iki yıl Çince hazırlık gördükten sonra dört yıllık lisans eğitimine başlatıldığı, sonuçta bir Uygur üniversite mezununun yaşıtı Çinlilerden iki sene geç mezun olması; kontenjan kısıtlaması ve popüler mesleklere girişin engellenmesi... vs. Fakat bölgeye yerleşen Çinlilerin yerlilere karşı her alanda üstünlüğü tam olarak sağladığı 
yıllardan sonra (1990) daha doğrudan, kaba ve yasalara aykırı uygulamalara başvurduğu gözlenmiştir. Bu uygulamalrın temel amacı bölgedeki halkının sosyal, kültürel ve psikolojik olarak Çinli toplumu ile bütünleşmesini sağlamak ve aradaki sosyo-kültürel, sosyo-psikolojik farkları asgariye indirmek veya sıfırlamak olmuştur. Bu doğrultuda, 2000 tarihinden itibaren eğitim ve kültür alanında benzeri görülmemiş uygulamaları hayata geçirmeye başlamıştır. Bu uygulamalardan en dikkat çekici olanı ise devlet destekli 新疆内地高中班/Xinjiang neidi gaozhong ban (Çin'in iç bölgesindeki Şinciang sınıfı) uygulamasıdır. ${ }^{19}$

Bu projeye dâhil edilen öğrenciler, genellikle Uygur Türkçesi ve yazısıyla eğitim yapan okullardan seçilen en başarılı, çalışkan veya istekli ortaokul öğrencilerden oluşmaktadır. Seçilen öğrenciler, Çin'in doğusundaki gelişmiş veya kalkınmış kıyı kentlerdeki liselerde özel olarak tesis edilmiş “Şinciang Sınıfı"nda yatılı olarak öğrenim görüyorlardı. 2004 yılında ilk mezunları verilmiş ve çoğu Çin'in iç kesimindeki çeşitli üniversitelere yerleştirilmiştir. Bu uygulama günümüzde de tüm hızı ile devam ettirilmektedir

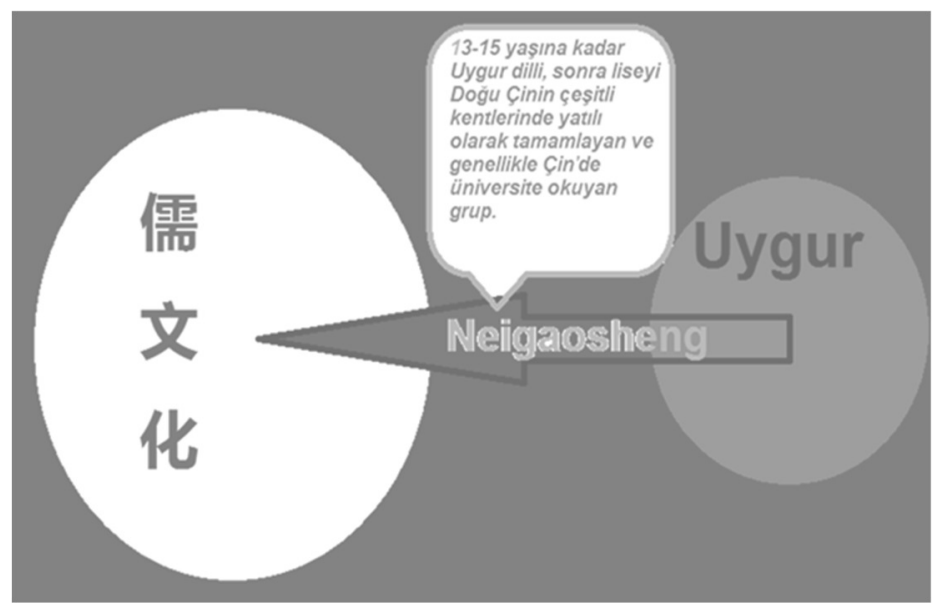

Şekil 3 Uygur toplumundan kopartılarak Çinli toplumu içine transfer edilen Neigaosheng grubu

Yaklaşık sekiz yıllık Çin'deki öğrenim süreci sonucunda oluşan kimlikleri dolayısıyla Uygur toplumunda daha çok "Neigaosheng"lar veya

19 Grose, Timothy A. (2010) 'The Xinjiang Class: Education, Integration, and the Uyghurs', Journal of Muslim Minority Affairs, 30: 1, 97-109 
kısaca "Neigao"lar olarak adlandırılmışlardır. Bu grubun özellikleri şu şekildedir:

Seçilen öğrencilerin yaşları 13-15 arasında olup, bu yaşına kadar kendi ailesinden ve doğup büyüdüğ̈̈ memleketlerinden hiç ayrllmamiştır. Gurbet nedir hiç bilmeyen bu çocuklar birden 6-7 bin kilometre uzakta bulunan, tamamen yabancı bir bölgede yatılı okumak üzere ailesinden, akrabalarından ayrılmışlardır. Geldikleri liselerde bir yıllık Çince hazırlık sonrasında Çinli öğrencilerin arasına dağıtılan Uygur ögrenciler, genellikle ortaokuldaki başartsını sürdürmekte zorlanmış ve çeşitli sorunlarla karşılaşmışlardır. Bu sorunların başında çeşitli ruhsal çöküntüler, iklimden dolayı ortaya çıkan çeşitli hastalıklar, Çinli öğrenciler tarafindan aşağılanma ve dışlanma, kebabçı, hırsı tarzında etiketlenmeler... Gittikleri liselerde ŞUÖB yönetimi tarafindan gönderilen yerel yöneticiler ve rehber ögretmenlerin denetiminde olan bu gençler, idari yönetim tarafindan 24 saat gözetim uygulanmuştır. İklim değişikliği, eğitim modeli ve müfredatının Uygur Türkçesinden Çinceye değişmesi umumiyetle şok etkisi yaratmış, öğrencilerin psikolojik yapılarında ciddi değişimlerin ortaya çıkmasına neden olmuştur. Daha neşeli, mutlu ve özgüveni yerinde olan gençler, bu süreç zarfinda içine kapall, çekingen, kendinden emin olamayan, çoğu zaman kararsız bireylere dönüşmeye başlamışlardır.

$\mathrm{Bu}$ politikanın uygulanma süreci ve sonuçları hükumetin beklediği şekilde olmamıştır. Özellikle verilen taahhütlerin yerine getirilmeyişi; öğrencilerin doğdukları yerlerde kazandıkları benlik şuuru ve mensubiyet algılayışları, geldikleri yerlerdeki sosyal ve psikolojik dışlanma durumları onların içine kapanmasına, pasif olsa dahi sürece direnmelerine neden olmuştur. Fakat Çin'de devam eden en az 8 yıllık eğitim sürecinde Uygur Türk kültüründen sürekli uzak kalmasını ve Çin kültürü ile sürekli kültürlenme durumunu ortaya çıkartmıştır. Bu durum, onlarda çeşitli psikolojik sorunların ortaya çıkmasına, Çin ve Uygur Türk kültürleri arasında sıkışıp kalmasına neden olmuştur.

Neigaosheng grubu Uygur Dilli Uygurlar ve Minkaohan'lere göre daha çok içine kapalı, zaman zaman psikolojik sorun yaşadıkları kolayca anlaşılabilen kimselerdir ki, Çinli toplumu dâhil kendi toplumundaki bahsi geçen gruplarla iletişimde zorlandıkları gözlenmektedir. Uygur dillileri kendilerine daha yakın görme eğilimi vardır. 
Çin dilli Uygurlar ${ }^{20}$ : Günümüz Uygur toplumunda, güdülen çeşitli (eğitim, kültür, sosyal, ekonomik ve dinî) politikalar sonucu farklı sosyal gruplar hızla çoğalmaya başlamıştır. Bu gruplar içinde en dikkat çekici olanı ise, son yarım asırlık süreçte yavaş yavaş ortaya çıkarak mevcut ŞUÖB idaresinin çeşitli kademelerinde ve memuriyette nicelik olarak baskın hale gelen Çin dilli Uygurlar grubudur.

Uygur Türk toplumunda ortaya çıkan farklı sosyal gruplar esasında, ÇKP'nin bölgede uygulamış olduğu eğitim ve kültür politikalarının sonucudur. İşbu politikalar ÇKP'nin bölgedeki egemenlik oranına paralel olarak olgunlaşmıştır. Başlangıçta kabul edilmiş olan azınlıkların dil ve

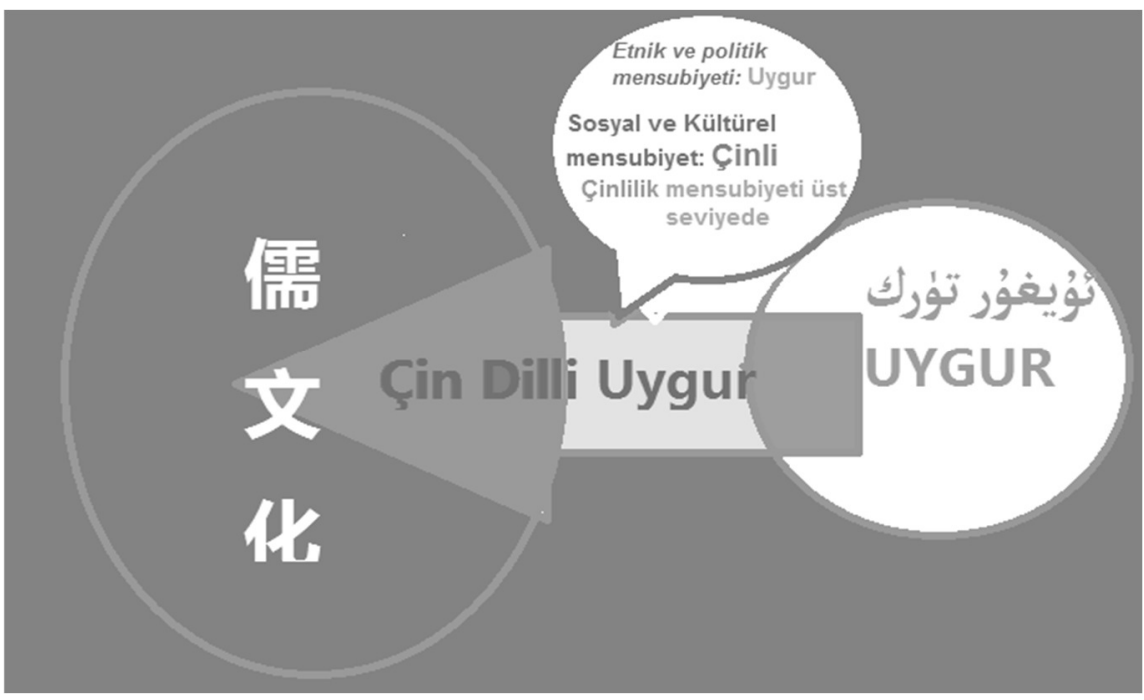

Şekil 4 Etnik mensubiyeti Uygur, fakat kültürel mensubiyeti Çinli olan Çin dilli Uygurlar grubu

kültürünün korunarak geliştirilmesi ile ilgili yasa ve yönetmeliklere nispi olarak riayet edilmiştir. Önceleri, Minkaohan benzeri grupların kademeli olarak ortaya çıkmasına, özendirilmesine münasip uygulamalar gerçekleştirdi ise, 11 Eylül saldırısı sonrası oluşan küresel konjonktüre uygun olarak iç siyasetinde radikal değişime gitmiş ve 2003 y1lından itibaren Çin dilli Uygurların hızla çoğalmasına zemin hazırlayan ve meşrulaştıran politikaları hızla uygulamaya başlanmıştır. Artık bu tarihten itibaren, ÇKP'nin

20 Uygur Türkçesindeki tam açılımı "Hanzu tillik Uygurlar" olan bu kavram, ilk olarak, Ekim 2005 tarihinde Pekin'de düzenlenen Merkezî Milliyetler Üniversitesi Uygur Dili ve Edebiyatı Bölümünün 2. yıldönümü münasebetiyle düzenlenen Uygur Dili Araştırmaları Sempozyumunda tarafımızdan ortaya atılmış idi (Karluk 2011: 39). 
TÜBAR XLII / 2017-Güz / Uygur Aydınlarda Bölünmüşlük ve Kültürel Kopukluk

milliyetler politikası radikal değişime uğramış, teritoryal özerklik yasası dâhil, din, dil, kültür yasaları bir kenara itilmiş ve uygulanmamıştır.

1990'lı yıllardan sonra nicelik olarak artmaya devam eden, özerk bölge yönetimindeki Uygur kökenlilerin bulunması gereken mevki makamlara atanmaya başlayan Çin dilli Uygurlar, sosyolojik açıdan incelendiğinde aşağıdaki gibi özellikleri bünyesinde barındırmaktadırlar.

\section{1. ÇKP'nin eğitim politikası ve ailevi kararlar Çin Dilli Uygurları or-} taya çıkartmıştır: Uygur özerk bölgesindeki eğitim sistemi 2003 yılına kadar Uygur Türkçesi, Çince, Kazak Türkçesi, Moğolca ile eğitim yapan kurumlardan oluşuyordu. Bölgenin esas yerli halkı olan Uygur Türklerinin eğitim sistemi, binlerce yıllık Türk-İslam eğitim sistemi temelinde değişerek gelişmiş sistem olup nispeten olgunlaşmış yapısı ile Çin'de Çince eğitim-öğretim yapan kurumlardan sonra gelmektedir. Bölgedeki Kırgız, Özbek, Tatar ve Tacik gibi diğer Türk ve akraba boyların çocukları da Uygur okullarına gönderiliyordu. Bütün dersler Uygur Türkçesinde okutulduğu gibi sinıflarda okutulan kitaplar, Uygur Türkü akademisyenlerce yazıldığı için Türk-İslam değerleri kısıtlı olsa da aktarılıyordu. Çinli okullarında okutulan ders kitapları ve müfredat, Çin milli eğitim bakanlığının müfredatı ve belirlenmiş ders kitaplarıdır.

Uygurların yoğun olarak yaşadıkları her bölgede Uygur okulları tüm kademesi ile mevcuttu. Fakat Uygurların yoğun olmadığı Bingtuan/兵团 ${ }^{21}$ yerleşim birimlerinde, askeri birimlerde, Çinlilerin yoğun olarak yaşadığ

21 Çin Kurtuluş Ordusu (ÇKO) tarafından 1954 yılında Doğu Türkistan'da kurulan yarı askeri yarı sivil görünümlü bir yapıdır. Şinciang Uygur Özerk Bölgesi hükumetinden tamamen bağımsız olarak doğrudan merkezî hükûmete karşı sorumlu olan Bingtuan, bu niteliği ile Çin Halk Cumhuriyeti'nde benzeri olmayan bir teşekküldür. 1954'ten bu yana kontrolünde bulundurduğu toprakları genişleterek büyüten Bingtuan'ın yüz ölçümü 2013 yllı itibari ile 70. 600 kilometrekaredir. Bünyesinde 14 tümen, 176 alay vardır. Bürokratik yetkilerinin de arttırılmasıyla günümüzde "devlet içinde devlet" olarak nitelendirilebilecek bir yapıya evirilmiştir. Resmi makamların verdiği istatistik verilere göre, 1954'teki nüfusu 175. 000 olan Bingtuan'ın nüfusu, günümüzde yaklaşık 3 milyon kişiye ulaşmış ve onlara istihdam olanağı sağlamaktadır. Bu iş gücünün mutlak çoğunluğunu Han Çinlileri oluşturmaktadır. (Bkz.: www.china.org.cn/ewhite/20030526/9. htm, erişim: 25. 12. 2016). Mao döneminden 20. yüzyılın sonlarına kadar Sovyet işgali ve etnik ayaklanmalara karşı emniyet supabı işlevi gören Bingtuan, Çin'in ekonomik atılım yaptığı 1990'lı yıllardan itibaren bölgedeki Han Çinli nüfusun sosyo-ekonomik üstünlüğünün muhafaza edilmesine, yerli halkın kuşatılması ve isyanların hızlı bir şekilde acımasızca bastırılmasına hizmet eden bir teşekkül olmuştur. Detaylı bilgi için bakınız: Donald Mcmillen, "Xinjiang And the Produnction and Construction Corps: A Han Organızation in a Non Han Region" The Australian Journal of Chinese affairs, 1981/6 P. 65-96; James D Seymour, "Xinjiang's Produnction and Construction Corps, and the Snification of Eastern Turkestan", Inner Aisa, 2000/2, P. 171-193. 
şehirlerde dağınık yaşayan Uygurlar, bulundukları bölgelerde yeteri sayıda Uygur nüfusu bulunmadığından dolayı çocuklarını Çinli okullarına göndermek mecburiyetinde kalmışlardır. Diğer taraftan, Çinli, Döngen gibi Çin dilli biri ile evlenen Uygur Türkü'nün çocukları da genellikle Çinli okullarına gönderilmiştir. Bu durum, daha sonraki süreçte Uygur dilli Uygurlardaki işsizliğin artması, üniversitelerde Uygur dillilere verilen kontenjanların kısıtlı oluşu, popüler meslekler ve fen-mühendislik alanlarında olmayışı gibi somut gerekçelerle yönetim kademesinde bulunan bazı Uygur aydınları kendi isteği ile çocuklarını Çin okullarına vermeye başlamıştir.

Özetlemek gerekirse, Çin dilli Uygur mensubu bireyler istisnai zorunluluk haricinde genellikle aile reislerin istekleri doğrultusunda, tamamen Çin dili ve kültürü ile eğitim-öğretim yapan kurumlara verilmesi sonucu eğitim kanalıyla kültürel Çinlileşme sürecine girmesi neticesinde ortaya çıkmıştır.

2. Sosyalleşme Süreci ve Kültürel Mensubiyetinin Çinlileşmesi: Çin dilli Uygurlar, ana okullardan itibaren resmî eğitim kurumlarında sosyalleşerek "Uygur dilli”" Uygurlardan farklı düşünce yapısına, yaşam tarzına, değer yargısına ve tarih şuuruna, hafızaya sahip olmuşlardır. Bundan dolayı, kültürel mensubiyet itibari ile daha çok Çin kültüründe sosyalleşen ve bu kültürde yetişen birey ya da gruplara tabidir veya onlara çok yakındırlar. Bundan dolayı, psikolojik olarak kendilerini daha çok Çin kültüründe yetişen birey ya da gruplara tabi hissederler veya onlarla daha yakın ilişki kurarlar. Onların milli hafızası Çinliler ile neredeyse aynıdır veya tamamen Çin tarzıdır. Gökalp'ın belirttiği üzere (1997: 228), “insan tabiiyeti aldığg terbiyeye bağlıdır ki, o kimin veya hangi milliyetin terbiyesini alırsa, onun için hizmet eder, ona çalışır, hatta kendini ona feda edebilir" tarzında bireyler olmuşlardır.

Çin dilli Uygurların birinci dili Çincedir. Uygur Türkçesini bilenler genellikle Çinceden çevirdikleri söz veya cümleyi konuşurlar. Yani kafalarında Çince kurdukları cümleleri bildiği Uygur Türkçesindeki sınırlı kelimelerle çevirmeye çalışırlar. Uygur Türkçesini asla orijinal Uygur Türkü gibi konuşamaz, ince duygularını Uygur Türkçesi ile ifade edemez, Uygur yazısıyla ilmî makale dâhil herhangi bir şekilde akademik üretimde bulunamazlar. Onların belki en önemli temsilcisi Uygur Özerk bölgesinde 2008-2014 yılları arasında bölge reisi olan ve halen Çin Halk Cumhuriyeti Enerji Kurumu başkanı olan Nur Bekridir. Nur Bekri'nin ŞUÖB reisi olduğu dönemde uygulamaya konan sözde "Çift dilli eğitim" ile ilgili olarak verdiği şu demeç Uygur Türklerinin hafızasına kazınmıştır: "Uygurlar «Çift dilli eğitim» politikasından şikâyet etmemeliler. Döngenlerin milli 
TÜBAR XLII / 2017-Güz / Uygur Aydınlarda Bölünmüşlük ve Kültürel Kopukluk

dilleri yoktur, ama Döngenler hala kültürel ve etnik mensubiyetini koruyorlar. Dolayısıyla Uygurların kendi dillerinde konuşmaması da o kadar önemli sorun değildir."

\section{Dinî İnançları ve Türk-İslam Değerlerine Yönelik Tutumları: Çin} dilli Uygurların en önemli özelliklerinden biri ise, İslam dininden soyutlanmış olmaları veya dinî duygularının çok zayıf olmasıdır. Büyüdüğü aile muhitinde dini değerler yaşatıllyorsa dahi eğitim süreci ve edindiği Çin kültüründen dolayı ya Ateist ya da seküler bir inanç tarzı benimsemişlerdir. İslam'a ve Müslümanlara bakışı ise genellikle menfi, soğuk veya olabildiğince mesafelidir. Eğer idari birimlerde çalışıor ise, mevcut bölge yönetiminin arzu ettiğinden ziyade din düşmanı olabilmektedirler.

Onlar, Uygur dili muhitinde yetişip Uygur Türkçesini kendilerine birinci dil seçen ve Türkçe düşünen aydınlar gibi Türk-İslâm merkezlerinden ilham almazlar ya da bu merkezlerle var olan geleneksel bağların korunmasından yana değiller. Tam tersine Çin'e ait olan kültür ve medeniyet merkezlerinden ilham ve feyz alma eğilimindeler. Bu tarz eğilimin, Uygur Türkleri arasında yaygın olması gerektiğini düşünür, geleneksel Türk-İslam merkezlerini, bu bölgeler ile kurulacak herhangi bir iletişimi bölge ve Çin çıkarları açısından tehlikeli bulurlar.

4. Yaşam Tarzı ve Ailevi Yaşantıları: Kültürel mensubiyetlerinden dolayı yaşam tarzı da mensubu olduğu Uygur Türk toplumundan uzaklaşma, Çinli toplumuna olabildiğince yakınlaşma ya da doğrudan onların bir ferdi gibi yaşama eğilimi sergilerler. Özellikle yeme içme alışkanlıkları zihniyeti ve yaşam tarzlarından dolayı genellikle Çince veya «Döngence»dir. Mutfağında baskın olan yemekler Çinlilere özgü olan kavurma çeşitleri veya beslenme alışkanlıklarıdır. Kimi Çin dilli Uygurlar dışarıda Çinlilere ait olan restoranlarda rahatça tüketimde bulunurlarken, kimileri yiyeceklerin sadece "döngence" denilebilecek olan "Qingzhen" ${ }^{22 "}$ olmasının yeterli olacağını savunurlar.

22 Qingzhen-清真 aslında helal veya İslami manasında kullanılan bir kavramdır. Fakat Çin genelinde veya yaygın kullanımı ise, tüketilecek yiyecekte İslamiyet'te haram kılınmış olan etlerden domuz, köpek, eşek eti gibi maddelerin bulunmaması şeklindedir. Bundan dolayı çoğu resmî kurumlarda, işletmelerde aynı Çinli yemekhanesi veya restoranda "Qingzhen" penceresi veya bölümü vardır. Böyle yerlerde, aşçıların Müslüman olup olmadığına pek dikkat edilmez. Çoğu zaman karıştırılır veya aslında aynı olan yemek farklı pencereden servis edilebiliyor. Buna benzer örnekleri yazar da bizatihi yaşamış veya şahit olmuştur. Bu sadece göstermelik veya orada bulunan Döngen ve diğer Müslüman kökenlilerin psikolojik olarak rahatlamasının sağlanması için uygulanan bir çeşit uygulamadan ibarettir. Örneğin, Pekin'de bulunan Milliyetler Yayınevinde birbirinden farklı onlarca milliyet mensubundan 200'e yakın personel çalışır. Bunların içinde sayıları 40'den fazla Uygur, Kazak, Kırgız ve Döngen milliyetlerine mensup Müslüman 
Giyim-kuşam tarzları ve estetiği ise, Uygur Türklerinden tamamen uzaklaşmış olup genellikle Çincedir. Özellikle kadınların giyim kuşamı ve estetiği belirgin derecede Çinlileşmiştir. En iyi gözlemlenen şekliyle Çin dilli Uygur kadınlar genellikle pantolon giyerler, etek ve uzun gömlek giymezler. Renk seçimleri tamamen Çince olup, canlı ve renkli giysileri tercih etmezler. Estetik alışkanlıkları ister bireysel güzellik anlayışı ister ev içi döşemelerde olsun Çin tarzıdır. Uygur Türklerine ait kültür unsurları evlerinde ve yaşamında ender rastlanır. Erkeklerin giyim kuşamı ise, genellikle Çin tarzıdır. Çinlilere ait olan kumaş ayakkabısını giymekte sakınca görmezler. Türklere özgü sakal, bıyık asla bırakmazlar ve bu tarz estetik anlayışları aşağılarlar. Saç stili genellikle Çinli olduğu gibi saçlarında beyaz saçların gözükmesine de tahammül edemezler ve Çinliler gibi sürekli siyaha boyarlar.

Arkadaşlık çevresi genellikle Çinli veya kendileri gibi Çin dilli olan kimselerdir. Etnik olarak mensubu olduğu milliyete yani Uygurlara dişardan biri veya "öteki" gözüyle bakarlar. Uygur dilli Uygurlar ile bir arada olduğundan kendini rahat hissedemez ve daima sıkılganlık içinde olurlar. Fakat Çin dilli milliyet ya da Çinlilerle bir arada olduğundan tamamen tersi görüntü sergiler ve çok rahat olabilirler. Bunları bulamadığında ise, Uygur dilliler arasından kendilerine en yakın gördükleri kültürel mensubiyeti gevşemiş, Çin tarzı yaşama açık olanlar ile ahbaplık ederler.

Eş seçmede Çinlilerden veya kendileri gibi Çin dilli Uygurlardan seçerler. Nadiren Çin dilli diğer azınlık milliyet mensuplarından da seçebiliyorlar. Onlara göre, Çinliler çalışkan, medeni ve geçinilebilir kimselerdir. Çin dilli Uygurlara göre, Uygur toplumunda kendilerini en iyi anlayanlar yine kendileri gibi Çin dilli olan Uygurlar veya Minkaohan'lerdir. Uygur dilli Uygurlar ile evlilik, genellikle düşünülmez ve istenilmez. Böyle bir evliliği yapanların mutlak çoğunluğu belli bir süre sonra boşanmışlardır.

kökenli personel vardır. Fakat birimde tek yemekhane mevcut olup, yemeklerin "Qingzhen” olduğu söylenir. Bütün personel öğle yemeğini, kimi zaman akşam yemeğini burada yerler. Uygur, Kazaklar nasıl kuzu etine düşkün iseler, Koreliler köpek etine, Çinliler domuz ve diğer İslamiyet'te yasaklanmış hayvan etlerine düşkündürler. Daha öteki milletlerin yemek zevki Türk kökenlilerden daha farklıdır. Burada çalışan farklı milliyet ve inançtan insanların aslında, dini inanç ve kültürel değerler bakımından kendi kültürlerine çoktan yabancılaşmış ve Çin devletinin belirlemiş olduğu "Zhonghua Minzu/Çin Miliyeti” kimliğini pasif olarak olsa dahi benimsediği, Çin kültürünün merkezindeki değerlerde birleşmeye başladığı görülür. İlginç olan ise, Müslüman kökenli milliyet mensupları işbu yemekhanede "haram" olan yiyeceklerin olabileceğini asla kabul etmezler. Fakat aşçıların, yemekhane çalışanlarının Müslüman olup olmaması ile ilgilenmezler. Bu tarz yemekhanelerin son yıllarda Uygur Özerk Bölgesindeki birçok resmi birimlerde veya işletmelerde gitgide yaygınlaştırıldığı, Müslüman-Çinli yemekhane ayırımının bölücülüğü körüklediği, milletler arası sınırları pekiştirdiği gerekçesiyle yasaklandığı saha çalışmalarımız esnasında gözlemlenmiştir. 
TÜBAR XLII / 2017-Güz / Uygur Aydınlarda Bölünmüşlük ve Kültürel Kopukluk

Onlara göre, kendi milliyeti içindeki evlenilebilecek adaylar belki Minkaohanler veya Çin kültürünü iyi benimsemiş olan Neigaoshenglerdir. Çocuk algılarına bakıldığında, Çinliler gibi genellikle erkek çocuk istemektedirler. Çok çocuk yapmak istemezler. Çocuklarına verdikleri kişi isimleri ise genellikle kısa ve Çincenin söyleniş ve yazılışına uygun adlardır. Kimi Çin dillilerin çocuklarına doğrudan Çince ad verdikleri de görülmektedir.

5. Öteki Gruplar ve Diğer Milliyetler İlişkileri: Burada israrla şunu belirtmeliyiz ki, üzerinde durulan "Çin dilli Uygurlar" ile Minkaohan'ler arasında çok ince bir ayırım vardır. Çin dilli Uygurlar denildiğinde doğrudan Minkaohan'lerın tamamını kesinlikle kast edilmemektedir. Fakat, Minkaohan'lerin büyük çoğunluğunun potansiyel "Çin dilli Uygurlar" olabileceği ima edilmektedir. Minkaohan'ler grubundaki kimselerin bazıları, ana okuldan itibaren Çince eğitim-öğretim sürecine katıldıysa, bazıları belli bir aşamada Çince eğitim sürecine dâhil olmuştur. Daha açık şekilde ifade edilmesi gerekirse, eğitim sürecinin belli bir dönemini Uygur okullarında geçirmiş, üniversite giriş sınavına Çince olarak katılmış ve ödül puanlardan yararlanarak Uygur dillilerden daha geniş kontenjan ve seçme şansını yakalamış olan kimselerdir. Böyle bireyler ise, Uygur Türkçesi ile yazısını biliyor ve Uygur Türk kültürünü nispeten iyi benimsemiştir. Bundan dolayı onların kimlik algılaması ve kültürel mensubiyeti daha çok Uygur dilli Uygurlar gibidir ${ }^{23}$. Fakat Minkaohan'lerin çoğunluğunu oluşturan kitle ise Çin dilli Uygur grubuna yakındır veya dâhildir.

Çin dilli Uygurların Uygur tarihi ve kültürü hakkındaki bilgileri ve yaklaşımı esasen «Çince»dir²4. Dolayısıyla, öteki gruplara bilhassa Uygur

23 Bakınız: Abdureşit Jelil Qarluq, (2006). "Til Bilän Kültürniñ Munasiveti”, Xinjiang Radio-Televiziyä Universiteti Jurnili, S. 3, Ürümçi. Ayrıca bakınız: Taynen, Jennifer, (2006), "Interpreters, Arbiters or Outsiders: The Role of the Minkaohanin Xinjiang Society”, Journal of Muslim Minority Affairs, Vol. 26, No. 1, pp. 45-62; Sean R. Roberts, (2007), “'Ethnic Anomaly' or Modern Uyghur Survivor? A Case Study of the Minkaohan Hybrid Identity in Xinjiang", Situating The Uyghurs Between China And Central Asia, Ed.: Ildikó Bellér-Hann, M. Cristina Cesáro, Rachel Harris, Joanne Smith Finley, Angland: Ashgate Publishing Company, pp. 219-239.

24 Çin resmi tarih tezi, Çin sınırları içindeki milliyetlerin tarihini “azınlık tarihi”, Han Çinlileri veya merkezi hanlıkların himayesi altında yaşamış, vergi ödeyen yerel beylikler tarihi olarak sunar. Türklerin ister Hun, Köktürk, Uygur ve Karahanl, Timur dönemlerinin asla bağımsız devletler, hanlıklar olduğunu kabul etmez. Kuzey ve Kuzeybatıdaki azınlık göçebeler olarak bahsedilir, detayına girilmez. Kaşgarlı Mahmut, Yusuf Has Hacip gibi bilginleri Karahanlı dönemi değil, Çin'in Song sülalesi döneminde yaşamış, Han Çinli kültüründen etkilenerek eser vermiş azınlık bilginleri şeklinde anlatılır. Çinliler ile bağımsızlık mücadelesi vermiş kahramanlar, devlet adamları ise eşkıya, hain, satılık unsurlar şeklinde tarif edilir. Aksini yazan, söyleyenler ise "bölücü", "ayrılıkç”", "Pantürkist/Panislamist" olarak cezalandırılır. 
dilli Uygurlara tepeden bakarlar, beğenmezler ya da Çinliler ile aynı pencereden bakarlar. Onların Çin kültürü ve değerleri etrafında dönüştürülmesi gerektiğini düşünür veya öyle olması için eğitim-kültür politikalarının geliştirilmesine zaman zaman öncülük ederler.

Uygur dilli Uygurlar ile bir arada olduklarında kendilerini rahat hissedemezler, sıkılganlık içinde olurlar veya çatışırlar. Fakat, Çin dilli biriyle veya Çinlilerle bir arada olduklarında ise, tamamen tersi görüntü sergiler ve psikolojik olarak onların yanında çok rahat olurlar. Dolayısıyla, Uygur dilliler ile olan ilişkilerde mesafeliler, tutumlarında daima Çinliliği yansıtırlar. Bundan dolayı Uygur Türk toplumunun selameti, Uygur kültürünün korunarak geliştirilmesi konusunda daha çok Çinlilerle hemfikirdirler.

Çin dili ve kültürünü, yaşam tarzı ve zihniyetini çok iyi benimsediklerinden ötürü Çinlilerle iletişim sıkıntısı bulunmamaktadır. Çinliler karşısında aşağılık kompleksine sahip olmalarından dolayı Çinli yöneticiler tarafından tercih edilmişlerdir. Günümüzde ŞUÖB'de Uygurların bulunması gereken idarî mevkilerin büyük çoğunluğu Çin dilli Uygurlara ve Minkaohanler'e verilmiştir.

Devletin Çin dilli Uygurlar ile (önemli oranda) Minkaohan'lere özerk bölge yönetimi ve idaresinde Uygur dilli Uygurlara nazaran çok fazla kontenjan ayırması, Uygur toplumunun aydın kitlesi arasında aslında var olan anlaşmazlık ve önyargıları daha da derinleştirmiş veya pekiştirmiştir. Çin dilli Uygurların önemli mevkilerde bulunmasına rağmen, Uygur Türk toplumundaki kültürel erozyon hızla devam etmiş, millî hafıza silinmeye devam etmektedir. Hatta bu sürece onların açıkça önayak olduğu bilinmektedir. Bundan dolayı, Toplumdaki çoğu Uygur dilli aydınlar, Çin dilli Uygurların etnik olarak mensubu olduğu toplumu sosyal, kültürel ve politik olarak temsil etmediğini veya edemeyeceğini düşünmektedirler. İlham Tohtı örneğindeki açık sözlü cesur aydınlar, işbu rahatsızlığı açıkça dile getirmiş ve gerekli eleştirilerini yapmıştır²5.

25 İlham Tohtı'nın Nur bekri hakkındaki görüşü için bakınız: Anthony Kuhn, Uighur Scholar Caught Up In China's Ethnic Conflict, http: //www. npr. org/templates/story/story. php?storyId=113620353, erişim: 20. 02. 2017; Life term for China scholar chills ethnic dialogue, By the Associated Press I September 23, 2014, http: //www. cnsnews. com/news/article/life-term-china-scholar-chills-ethnic-dialogue, Erişim: 20. 02. 2017. 
Onların milli dil, din, kültür ve örf adet hususundaki radikal Çinci tutumlarından ötürü halk tabakası tarafından hoş karşılanmayan, istenmeyen kimselere dönüşmüştür. Daha da ileri gidilerek onları Şinciang'daki 14. Milliyet, Çin'deki 57. Milliyet olarak görmüşlerdir.

\section{Değerlendirme}

Uygur Türk toplumu ÇKP iktidarı sürecinde sürekli olarak yönetim ve rejimin değiştirme ve dönüştürme hedefi olmuştur. Bu süreç 1955 y1lında başlamış, 1966-1976 yılları arasındaki meşhur 'kültür devrimi' sürecinde zirveye ulaşmıştır. 1979 sonrası, Çin genelindeki yumuşama sürecinde Uygur Türk toplumunun 'nefes alması'na imkân vermiştir. Fakat, ÇKP yönetimi engin devlet tecrübesi ile SSCB' nin çökmesi ve dağılması sonrasında oluşan küresel konjonktürden ders çıkartmayı bilmiş ve mutedil milliyetler politikasından vaz geçmiştir. Buna göre, Uygur, Tibet politikasında mevcut yürürlükteki ilgili yasaları kenara iterek, çok farklı bir süreci adına sosyo-kültürel asimilasyon süreci denilebilecek yeni bir süreci başlatmıştır. 11 Eylül saldırıları, işbu politikanın daha ileri versiyonlarının icrasına küresel imkân tanımış, Uygur Türk toplumunun kültürel omurgası kırılmaya başlanmıştır.

Bütün bu süreçteki uygulama ve icraatlar Uygur Türk toplumunun zorunlu olarak kendi yörüngesinden çıkması, toplumun sosyal ve kültürel olarak parçalanması, bölünmesi ve nihayetinde zayıflatılması sonucunu ortaya çıkartmıştır. Özellikle uygulanan eğitim ve kültür politikaları aydınlar arasındaki bölünmeyi hızlandırmış ve birbirinden farklı sosyal grupları ortaya çıkartmıştır.

Özetle, Uygur dilli Uygurlar grubu günümüzde nitelik ve nicelik olarak gerileme sürecine girmiştir. Minkaohan grubu, yerini gitgide Çin dilli Uygurlara birakırken, Neigaosheng grubu ise, mevcudiyetini korumaktadır. Eğer ŞUÖB yönetiminin mevcut dil, kültür ve eğitim politikası değişmeden devam edecek olursa, Uygur Türk toplumundaki aydınların çoğunluğunu Çin dilli Uygurların oluşturacağı öngörülebilir.

Üzerinde durulan "Çin dilli Uygurlar" grubu günümüz Uygur Türk toplumundaki Minkaohan grubunu kast etmemekte, fakat Minkaohan'lerin büyük çoğunluğunun "Çin dilli Uygurlar" olabileceği gerçeğine de vurgu yapılmaktadır. Çünkü Uygur kökenli Minkaohanler genellikle Çin dilli grubun özelliklerini taşıyorlar. Böyle olmasının temel nedenlerinden biri ise, Uygur Türk kültürü ile Çinli kültürü arasında geçişkenliğin hiç denecek kadar olmamasıdır. Çinceyi birinci dil olarak benimseyen birinin, Uygur Türkçesini kolay öğrenememesi, öğrense de Türk İslam kültürünü özümsemesinin zorluğudur. 
Diğer taraftan, dil-kültür ve zihniyet ilişkileri bağlamında, Çinceyi birinci dil olarak benimsemiş bireylerde, Çin kültürü ve bu kültüre ait davranış kalıplarının iyice yerleşmesi sonucunda Çinlilerde var olan ötekilere bakış açısının yerleşmesi ve ötekileri aşağılama tutumunun içselleştirilmesi sonucunda kültürel mensubiyet etnik mensubiyetin önüne geçebilme gerçeğidir. Yani Çin dilli bireyde Çinlilerde var olan Çin benliği ve kimliğini üstün tutma ve gayri Çinlileri özellikle azınlık konumunda olanlara yönelik aşağılama, dışlama zihniyetinin dışa vurması ile etnik olarak mensubu olduğu topluma mesafeli durulması veya tepeden bakılması durumunun ortaya çıkmasıdır. Diğer taraftan etnik olarak Çinli olmayan biri Çinlilere kendini kabul ettirmek için Çinliden daha Çinli olması, öncü/avangart olması durumunu ortaya çıartmıştır. Bu durum, Çin'deki Han Çinli-azınlık ilişkilerinde sıklıkla yaşanan bir durumdur. Minkaohan grubu içinde çok az sayıdaki bireylerin Uygur Türkçesini, yazısını ve kültürünü nispeten iyi benimsemiş olduğu, kültürel mensubiyet ve kimlik algılamasında daha çok Uygur dilli Uygurlara yakın durduğu da bir gerçektir. Bu tarz aydınların Çinlilerle olan ilişkilerde kendi toplumunun hak ve hukukları için daha mantıklı öneriler sunabildiği de bilinmektedir.

Bölgede yaptığımız saha çalışmaları, Uygur dilli Uygurların mutlak çoğunluğun ve önemli sayıdaki Neigaosheng mensuplarının, Minkaohan ve Çin dilli Uygurlardan şöyle beklentilerinin olduğu anlaşılmıştır: Onlar göre, Minkaohan ve Çin dilli Uygurlar, Uygur toplumu ile Çinli toplumu arasında köprülük işlevi görmeliydiler, Çünkü Minkaohan ve Çin dilli Uygurlar doğdukları toplum ve biyolojik mensubiyetlerinden dolayı Uygur tabiiyetindeler, fakat aldıkları eğitimlerinden dolayı ise Çinlilere daha yakın ve Çinlilerle çok iyi iletişim kurabiliyorlardı. Bundan dolayı, onlar iki toplum arasındaki iletişimin kolaylaştırılması ve mevcut yasalarda vaat edilen hakların elde edilip uygulanmasına yardımcı olmaları ise onların aslı görevleri idi.

Fakat zamanla işbu grup mensuplarının tam tersi davranışları ile Uygur Türk toplumunun ekseriyetinde hayal kırıklığı yaşatmakta oldukları anlaşılmıştır. Ortaya çıkan bu durum, Uygur toplumundaki bahsi geçen gruplar arası ilişkilere menfi etki yapmış, gruplar arası mesafe giderek açılmıştır. Elbette, yöneticiler de bu durumdan iyice istifade ederek süreci kendi lehlerine yönetmişlerdir.

Kültürel kopukluk hadisesi, toplumun parçalanması ve yarılması sonucunda ortaya çıkar. Genellikle toplumun parçalanması ve yarılmasına, toplumun tabakalaşması ve bölünmesi neden olur. Toplumun tabakalaşması ve bölünüşüne ise, ilgili toplumda ssrarla uygulanan politikalar, reformlar ve zoraki değiştirmeler neden olabilir. Uygur Türk toplumunda ortaya çıkan kültürel kopukluk veya kültürel yabancılaşma olgusunun en 
TÜBAR XLII / 2017-Güz / Uygur Aydınlarda Bölünmüşlük ve Kültürel Kopukluk

önemli nedenlerinden biri ülke genelinde icra edilen tek kültürcü din, dil, eğitim ve kültür politikası ve onun ŞUÖB' deki şovenist tarzda uygulanmasidır.

\section{KAYNAKÇA}

ÂTIF, Mehmed (1999), Kaşgar Tarihi (Bâis-i Hayret Ahvâl-i Garibesi), haz. İsmail, Vehbi, Cahit, Eysi Yayınları, Kırıkkale.

BARNETT, A. Doak (1961), China On the Eve of Communist Takeover, New York: Praeger.

BECQUELINE, Nicholas (2004), "Criminalizing Ethnicity: Political Repression in Xinjiang" China Rights Forum 1 (2004).

BOULGER, Demetrius C. (1878), The Life of Yakoob Beg (Athalik Ghazi, and Badaulet; Ameer of Kashgar), Wm. H. Allen \& Co., London.

BOVINGDON, Gardener (2002), "The Not-So-Silent Majority: Uyghur Resistance to Han Rule in Xinjiang" Modern China 28, no. 1 (January 2002): 39-78.

BROPHY, David (2016), Uyghur Nation. Harvard University Press.

CAPPELLETTI, Alessandra (2016), "Socio-economic disparities and development gap in Xinjiang: the cases of Kashgar and Shihezi", Edited by Anna Hayes, Michael Clarke, Inside Xinjiang Space, Place and Power in China's Muslim Far Northwest, Routledge.

DİJKSTRA, Edsger W. (1986), On a cultural gap. The Mathematical Intelligencer, $8(1), 48-52$.

DWYER, Arienne M. (2005), The Xinjiang Conflict: Uyghur identity, language policy, and political discourse. Policy Studies, (15).

ERKIN Türkler, "Sincan: Çin'in başarılı alg1 operasyonu”, Türk Yurdu, Sayı 331, Mart 2015, S. 27-28, Ankara.

FREEBERNE, Michael (1966), "Demogtaphic and Economic Changes in the Sinkiang Uighur Autonomous Region", Population Studies, Vol. 20, No. 1, pp. 103-124.

GROSE, Timothy A. (2010), "The Xinjiang Class: Education, Integration, and the Uyghurs", Journal of Muslim Minority Affairs, 30: 1, pp. 97-109.

GUPTA, Sonica \& VEENA Ramachandran (2016), Bilingual Education in Xinjiang in the Post-2009 Period. China Report, 52(4), 306-323.

HANN, Chris (2014), Harmonious or Homogeneous? Language, education and social mobility in rural Uyghur society. On the fringes of the harmonious society: Tibetans and Uyghurs in socialist China, 183-208. 
HAYİT, Baymirza (1975), Türkistan Rusya ile Çin Arasında, çev. Abdülkadir Sadak, Otağ Yayınları, Ankara.

JAMES D Seymour, "Xinjiang's Produnction and Construction Corps, and the Snification of Eastern Turkestan”, Inner Aisa, 2000/2, P. 171-193.

JİA, Jianfei (2011), Whose Xinjiang? The Transition in Chinese Intellectuals' Imagination of the" New Dominion" During the Qing-Dynasty. Harvard-Yenching Instıtute Working Paper Serıes, S. 1-16.

KAMALOV, Ablet, (2007), "The Uyghurs as a Part of Central Asin Communality: Soviet Historiography on the Uyghurs", Situating The Uyghurs Between China And Central Asia, Ed.: Ildikó Bellér-Hann, M. Cristina Cesáro, Rachel Harris, Joanne Smith Finley, Ashgate Publishing Company, Angland.

MA Dazheng/马大正. (2016). Şincang'da "Radikallığı Yok etme" mücadelesinin araştırılması/ 新疆 “去极端化” 斗争探究. 新疆师范大学学报, 37(5), 15 .

MCMILLEN, Donald (1981), "Xinjiang And the Produnction and Construction Corps: A Han Organızation in a Non Han Region" The Australian Journal of Chinese affairs, 1981/6 P. 65-96;

ONDR`EJ KLIMEŠ Struggle by the Pen: The Uyghur Discourse of Nation and National Interest, c. 1900-1949. By. Leiden: Brill.

QARLUQ, Abdürreşit Jelil (2006), “Til Bilän Kültürniñ Munasiveti”, Xinjiang Radio-Televiziyä Universiteti Jurnili, S. 3, Ürümçi.

(2007), “Ceditçilik Hareketi-Türk İslam Kültürünün Yenileşme Girişimi/ 浅谈哲迪特运动一突厥伊斯兰文化的现代化运动”, Milliyetler Araştırması Külliyatı/民族研究文集Minzu Yanjiu Wenji, Milliyetler Üniversitesi Yayınevi, 2007, 275-288, Pekin.

(2007), "Musabayuf Ailesinin Şincang Yenileşmesi Sürecine Katkıları Üzerine İnceleme/穆萨巴耶夫家族对新疆社会现代化的贡献初探”,

Milliyetler Araştırması Külliyatı/民族研究文集Minzu Yanjiu Wenji, Merkezi Milliyetler Üniversitesi Yayınevi, 2007, 260-275, Pekin, (Çince);

(2009), “Çin Halk Cumhuriyeti’ndeki Milliyetlerin Dağılımı ve Etno-Demografik Özellikleri”, Hacettepe Üniversitesi Türkiyat Araştırmaları Dergisi, 2009 Güz (11), s. 63-90, Ankara.

(2009), "Uygur Yenilesme Sürecindeki İstanbul Ekolü ve Onun Bazı Temsilcileri Üzerine”, Türk Kültürü̈, 2009/2, 290-328, Ankara;

(2010), “Uygur Yenileşme sürecinde 'İstanbul Ekolünün' Etkisi üzerine”, Türk Kültürü, 2010/2, 72-112, Ankara. 
TÜBAR XLII / 2017-Güz / Uygur Aydınlarda Bölünmüşlük ve Kültürel Kopukluk

(2011), Uygur toplumundaki Kültürel Kopukluk Olgusu, Xinjiang Sosyal Bilimler Akademisi Dergisi, 2011/1, Sayfa: 29-39, Ürümçi, (Uygur Türkçesi).

SAYRAMİ, Molla Musa (1986), Tarihi Hamidi, haz. Enver Baytur, Pekin Milletler Neşriyat1, Pekin.

SEAN R. Roberts, (2007), “Ethnic Anomaly” or Modern Uyghur Survivor? A Case Study of the Minkaohan Hybrid Identity in Xinjiang", Situating The Uyghurs Between China And Central Asia, Ed.: Ildikó Bellér-Hann, M. Cristina Cesáro, Rachel Harris, Joanne Smith Finley, Angland: Ashgate Publishing Company, pp. 219-239.

SEYMOUR James D. (2000), “Xinjiang's Produnction and Construction Corps, and the Snification of Eastern Turkestan", Inner Aisa, 2000/2, P. 171-193.

SCHLUESSEL, Eric T. (2007), "Bilingual' education and discontent in Xinjiang", Central Asian Survey, 26: 2, 251-277.

TAYNEN, Jennifer, (2006), "Interpreters, Arbiters or Outsiders: The Role of the Minkaohanin Xinjiang Society", Journal of Muslim Minority Affairs, Vol. 26, No. 1, pp. 45-62.

TYSON, A., \& Wu, X. (2016), Ethnic Conflict and the New Legalism in China. Nationalism and Ethnic Politics, 22(4), 373-392.

WAİTE, Edmund, (2007). "The Emergence of Muslim Reformism in Contemporary Xinjiang: İmplications for the Uyghrs' Positioning Between a Central Asian and Chinese Context", Situating The Uyghurs Between China And Central Asia, Ed.: Ildikó Bellér- Hann, M. Cristina Cesáro, Rachel Harris, Joanne Smith Finley, Angland: Ashgate Publishing Company

ZHANG, Zhızhong (1987), Ürümçi Söhbetidin Xinjiang Tinç Azat Bolğanğa Qädär, Çinceden Çeviren Razaq Malik, Ürümçi: Xinjiang Hälq Näşiriyatı.

\section{Elektronik Kaynaklar:}

Anthony Kuhn, Uighur Scholar Caught Up In China's Ethnic Conflict, http: //www. npr.org/templates/story/story.php?storyId=113620353, erişim: 20.02. 2017

Life term for China scholar chills ethnic dialogue, By the Associated Press I September 23, 2014, http: //www.cnsnews.com/news/article/life-termchina-scholar-chills-ethnic-dialogue, Erişim: 20.02.2017.

www.china.org.cn/e-white/20030526/9.htm, erişim: 25.12.2016. 